\title{
The Valais units in Savoy (France) A key area for understanding the palaeogeography and the tectonic evolution of the Western Alps
}

\section{Journal Article}

Author(s):

Loprieno, Andrea; Bousquet, Romain; Bucher, Stefan; Ceriani, Stefano; Dalla Torre, Florian H.; Fügenschuh, Bernhard; Schmid, Stefan M.

Publication date:

2011-07

Permanent link:

https://doi.org/10.3929/ethz-b-000037751

Rights / license:

In Copyright - Non-Commercial Use Permitted

Originally published in:

International Journal of Earth Sciences 100(5), https://doi.org/10.1007/s00531-010-0595-1 


\title{
The Valais units in Savoy (France): a key area for understanding the palaeogeography and the tectonic evolution of the Western Alps
}

\author{
Andrea Loprieno - Romain Bousquet - Stefan Bucher • \\ Stefano Ceriani • Florian H. Dalla Torre • \\ Bernhard Fügenschuh $\cdot$ Stefan M. Schmid
}

Received: 24 March 2010/Accepted: 29 August 2010 / Published online: 1 October 2010

(C) Springer-Verlag 2010

\begin{abstract}
The Valais units in Savoy (Zone des Brèches de Tarentaise) have been re-mapped in great detail and are subject of combined stratigraphic, structural and petrological investigations summarized in this contribution. The sediments and rare relics of basement, together with Cretaceous age mafic and ultramafic rocks of the Valais palaeogeographical domain, represent the heavily deformed relics of
\end{abstract}

\section{S. M. Schmid ( $\square)$}

Geologisch-Paläontologisches Institut der Universität Basel, 4056 Basel, Switzerland

e-mail: stefan.schmid@unibas.ch

\author{
A. Loprieno \\ Frazione Gimillan 28, 11012 Cogne, Aosta, Italy \\ e-mail: andrea.loprieno@unibas.ch \\ R. Bousquet \\ Institut für Geowissenschaften Universität Potsdam, \\ 14476 Potsdam, Germany \\ e-mail: Romain.Bousquet@geo.uni-potsdam.de \\ S. Bucher \\ Muséum d'histoire naturelle de Neuchâtel, \\ 2000 Neuchâtel, Switzerland \\ e-mail: stefan.bucher@unine.ch \\ S. Ceriani \\ Geologic Consultancy, Hirsmühleweg 14, \\ 8158 Regensberg, Switzerland \\ e-mail: ceriani_vandaalen@yahoo.de \\ F. H. Dalla Torre \\ Laboratory for Metal Physics and Technology, \\ ETH Zurich, 8093 Zurich, Switzerland \\ e-mail: Florian.DallaTorre@gmx.ch \\ B. Fügenschuh \\ Geology and Palaeontology at Innsbruck University, \\ 6020 Innsbruck, Austria \\ e-mail: Bernhard.Fuegenschuh@uibk.ac.at
}

the former distal European margin (External Valais units) and an ocean-continent transition (Internal Valais unit or Versoyen unit) that formed during rifting. This rifting led to the opening of the Valais ocean, a northern branch of the Alpine Tethys. Post-rift sediments referred to as "Valais trilogy" stratigraphically overlie both External and Internal Valais successions above an angular unconformity formed in Barremian to Aptian times, providing robust evidence for the timing of the opening of the Valais ocean. The Valais units in Savoy are part of a second and more external mid-Eocene high-pressure belt in the Alps that sutured the Briançonnais microcontinent to Europe. Top-N D1-deformation led to the formation of a nappe stack that emplaced the largely eclogite-facies Internal Valais unit (Versoyen) onto blueschistfacies External Valais units. The latter originally consisted of, from internal to external, the Petit St. Bernard unit, the Roc de l'Enfer unit, the Moûtiers unit and the Quermoz unit. Ongoing top-N D2-thrusting and folding substantially modified this nappe stack. Post $35 \mathrm{Ma}$ D3 folding led to relatively minor modifications of the nappe stack within the Valais units but was associated with substantial top-WNW thrusting of the Valais units over the Dauphinois units along the Roselend thrust during W-directed indentation of the Adria block contributing to the formation of the arc of the Western Alps.

Keywords Alpine geology · Valais ocean · Palaeogeography $\cdot$ Structural geology $\cdot$ Tectonics . Metamorphism

\section{Introduction}

In Savoy, the tectonic units derived from the Valais palaeogeographical domain, first defined by Haug (1909) then revived by Trümpy (1955), mark the front of the Penninic 
nappes that bend around the northern part of the arc of the Western Alps, connecting with the E-W striking Zone de Sion-Courmayeur in adjacent Switzerland and ending in a $\mathrm{N}-\mathrm{S}$ striking segment south of our area of investigation (Fügenschuh et al. 1999; Ceriani et al. 2001). Ophiolitic rocks have been known for a long time to occur within the Valais palaeogeographical domain in two key areas of the Western Alps. One is located near Visp in Switzerland (e.g. Dietrich and Oberhänsli 1975), the other, often referred to as the Versoyen (Elter and Elter 1965), is object of this study (Fig. 1).

First, and most importantly, this contribution aims to summarize and synthesize new unpublished data on stratigraphy and structures (Dalla Torre 1998; Bucher 1999; Loprieno 2001) as well as partly published findings on the metamorphic evolution (Bousquet et al. 2002) obtained from the study area (see also Fügenschuh et al. 1999 for a preliminary publication of some of this work). Second, these findings will be discussed in the context of recently renewed controversies regarding the existence (e.g. Frisch 1979; Stampfli 1993; Stampfli et al. 1998) or non-existence (e.g. Schärer et al. 2000; Manatschal 2004;

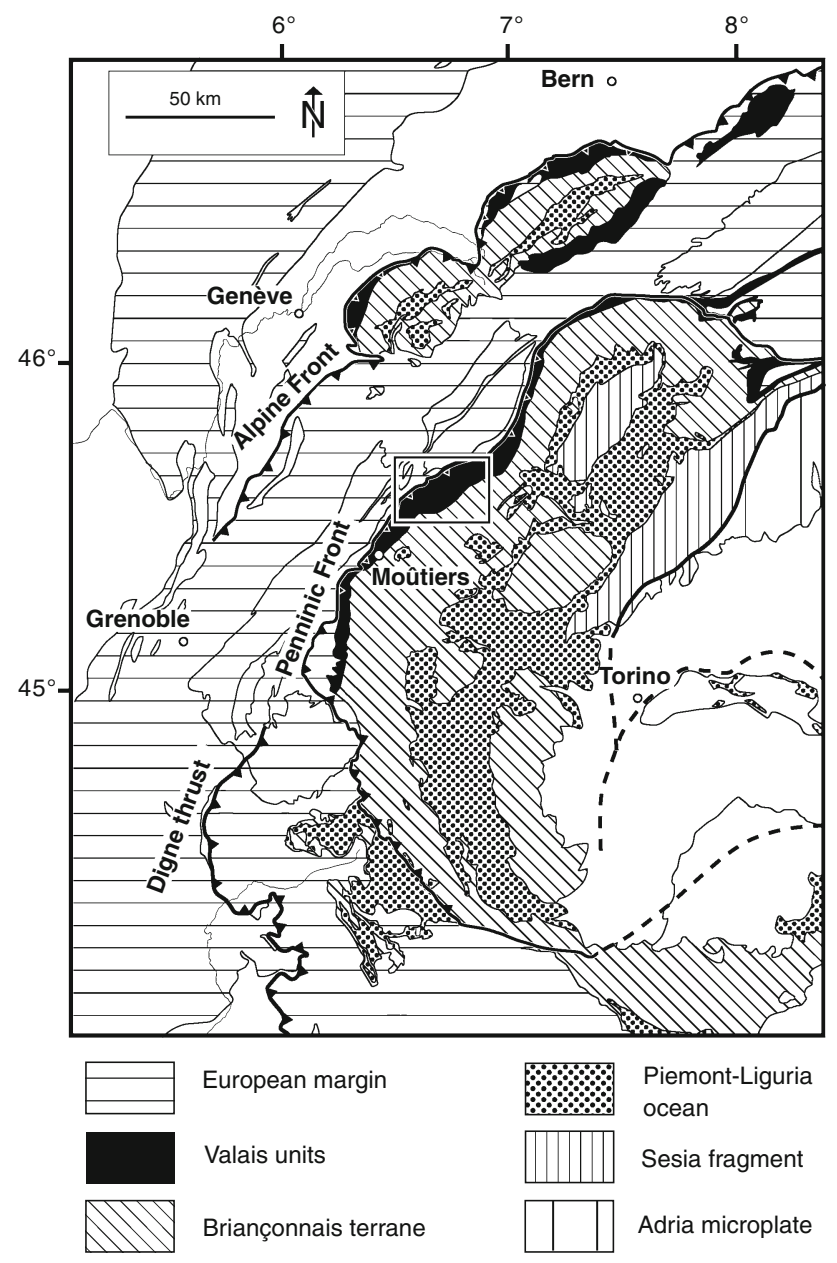

Fig. 1 Location of the working area within the arc of the Western Alps (after Schmid et al. 2004). Rectangle indicates the outlines of Fig. 2
Beltrando et al. 2007; Masson et al. 2008) of a Cretaceous age Valais ocean. Finally, we will briefly discuss the significance of these new findings for the palaeotectonic and orogenic evolution of the Western Alps.

\section{Geological overview}

The area of investigation (Fig. 2) is located north of Bourg St. Maurice (Val d'Isère, Savoy, France) and extends eastward beyond the Col du Petit St. Bernard located at the French-Italian border. Figure 2 presents a new tectonic map based on detailed structural and lithological maps of the area at the 1:10,000 scale (Dalla Torre 1998; Bucher 1999; Loprieno 2001).

The Valais units in the area, also referred to as Zone des Brèches de Tarentaise (Antoine 1971), are bounded to the NW by tectonic slices consisting of sediments derived from the European margin, i.e. the Dauphinois realm. These tectonic slices (Unité du Rocher du Vent and unité de la Crête des Gittes; Eltchaninoff and Triboulet 1980) are thrust onto the Mont Blanc massif including its thin sedimentary cover in stratigraphic contact. The tectonic slices represent the root zone of the Helvetic Wildhorn nappe exposed in Western Switzerland (Trümpy 1951, 1963; Grasmück 1961; Epard 1990). The top-WNW Roselend thrust, also referred to as Penninic Front (Ceriani et al. 2001), forms the tectonic boundary of the Dauphinois with the overlying and more internal Valais units. To the SE, the Valais units are separated from the Zone Houillère by a late-stage normal fault (Fügenschuh et al. 1999) that reactivated a former frontal thrust of the Zone Houillère (Bucher et al. 2003), i.e. the frontal part of the Briançonnais derived from a microcontinent located between the Valais and Piemont-Liguria branches of the Alpine Tethys (e.g. Stampfli 1993; Froitzheim et al. 1996; Schmid et al. 2004). The Zone Houillère mainly consists of Carboniferous and Permian sandstones, breccias and shales of continental origin and contains only subordinate Early Triassic dolomites and shales in the area of investigation (Bucher et al. 2004).

Further south and along strike, the Valais units, including the Cheval Noir unit, wedge out in map view between the Dauphinois realm and Zone Houillère (Fig. 1; Ceriani et al. 2001). The Cheval Noir unit represents the remnants of a trench formed during the subduction of the Valais units and is made up of a thick series of Tertiary (mainly Priabonian) sediments (wildflysch, breccias and flysch), which rest on a Briançonnais type substratum (Serre et al. 1985; Ceriani et al. 2001; Ceriani and Schmid 2004). Further south, Valais units s. str. and Cheval Noir unit are "replaced" by the Subbriançonnais units that are derived from a more external part of the Briançonnais microcontinent (Fügenschuh et al. 1999). These Subbriançonnais units consist of a stratigraphic sequence starting with Late Triassic dolomites and shales and ending with Oxfordian shales. 


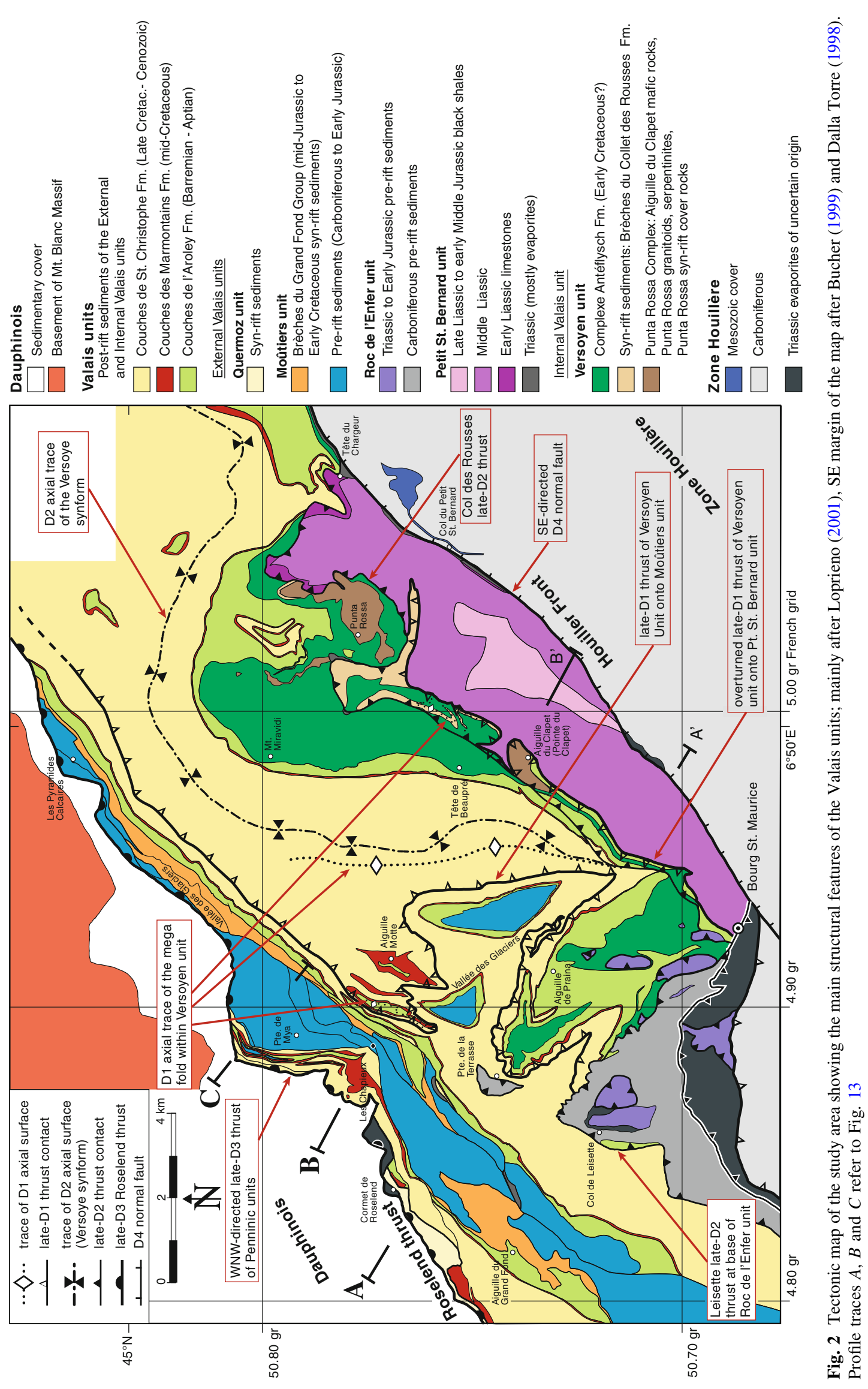


All Valais units within the working area, with the exception of the Petit St. Bernard unit, carry the same type of youngest stratigraphic cover, classically referred to as "Flysch de Tarentaise" or "Flysch Valaisan" (e.g. Antoine et al. 1992; Fudral 1998) in France and called "Valais trilogy" in adjacent Western Switzerland (Burri 1979; Jeanbourquin 1994). This Valais trilogy consists of the Aroley, Marmontains and Saint Christophe formations. These clastic post-rift sediments (Fig. 2) are of Barremian-Aptian (Trümpy 1954; Elter and Elter 1965; Sodero 1968) to probably Tertiary age and are diagnostic for the Valais palaeogeographical domain. The substratum onto which these post-rift sediments were laid down is classically referred to as "Substratum" or "Complexe Antéflysch" (Antoine 1971), depending on whether the postrift sediments were deposited onto Mesozoic sediments of Permian to Early Jurassic age belonging to the distal European margin (External Valais units) or onto black schists intercalated with mafic sills characteristic for the Valais ocean (Internal Valais unit).

Below, we briefly introduce the main tectonic units of the Valais palaeogeographical domain found within our area, going from an originally more external (NW) to an originally more internal (SE) palaeogeographical position.

\section{Quermoz unit}

This frontal most External Valais unit (Antoine et al. 1992), not subject of this study, reaches the westernmost part of the area depicted in Fig. 2. There and further to the $\mathrm{SW}$, it forms a thin basal sliver of the Valais units. The flysch-type sediments of the Quermoz unit, typically breccias, are considered a very external part of the Valais palaeogeographical domain and a lateral equivalent of the Niesen nappe in Switzerland (Homewood et al. 1984).

\section{Moûtiers unit}

Antoine (1971) originally divided the Valais units into the Moûtiers unit and the Roignais-Versoyen unit, a subdivision that remained unchanged since (Antoine et al. 1992, 1993). However, following Loprieno (2001), we draw the boundary between these two units differently (compare Fig. 2 with the tectonic map found in Antoine et al. 1992), and we change the name "Roignais-Versoyen unit" into Versoyen unit for two reasons. First, the boundary between the External Valais units (Moûtiers unit) and the Internal Valais unit (=Versoyen unit), as drawn in Fig. 2, follows the palaeogeographical and stratigraphic scheme discussed later (see Figs. 3, 4). We attribute those parts of the post-rift sediments that we interpret to have been laid down on the Permo-Mesozoic sediments of the continental margin, such as those found in the Roignais area, to the Moûtiers unit that is a part of the External Valais units. This results in a lager Moûtiers unit at the expense of the former "Roignais-Versoyen unit" (compare Fig. 2 with the tectonic map in Antoine et al. 1992). Second, we mapped the boundary between the Moûtiers and Versoyen units by following the trace of a late-D1-thrust ("late-D1thrust of Versoyen unit onto Moûtiers unit" in Fig. 2) that will be described when discussing the structures of the area.

\section{Roc de l'Enfer unit}

The attribution of the Roc de l'Enfer unit (Barbier 1948; Antoine 1971; Antoine et al. 1992, 1993; Fudral 1980, 1998) was much debated in the literature. This unit overlies the Versoyen unit along the late-D2 Leisette thrust, starts to appear in map view near Bourg St. Maurice (Fig. 2) and extends for some $30 \mathrm{~km}$ further to the SW to the area around Moûtiers (Loprieno 2001). It predominantly consists of Carboniferous schists with occasional remnants of Mesozoic sediments, structurally located between the Zone Houillère in the hangingwall and undisputed parts of the Valais domain in the footwall (External and Internal Valais units). Three different thrust-sheets were recognized within the Roc de l'Enfer unit (Fig. 2; see Loprieno 2001 for more details). The thrust sheet consisting of Carboniferous beds forming the main body of the Roc de l'Enfer unit was also referred to as "Faisceau de Salins" (Barbier 1948). Mapping (Fig. 2) revealed a new subdivision of the Roc de l'Enfer unit, and, most importantly, it revealed that the Carboniferous strata of this unit are stratigraphically overlain by the Aroley Formation (post-rift sediments) near the Col de Leisette (Fig. 2; Loprieno 2001), i.e. a lithology that is diagnostic for the Valais units. Also, our re-mapping revealed the existence of a small klippe of the Roc de l'Enfer unit near the Pte. de la Terrasse peak (Fig. 2). There, lithologies previously interpreted as belonging to the Marmontains Formation (Antoine et al. 1992, 1993) turned out to be Carboniferous schists preserved in a folded small klippe of the Roc de l'Enfer unit.

In summary, the Roc de l'Enfer unit is made up by prerift sediments (Carboniferous and more rarely Triassic) that are stratigraphically overlain by post-rift sediments above an angular unconformity near the Col de Leisette. The stratigraphy is identical to that observed in the Moûtiers unit (Loprieno 2001), and hence this unit is considered as another part of the External Valais units. However, as will be discussed later, the Roc de l'Enfer unit structurally overlies the Versoyen (Internal Valais unit) along a late-D2 out-of-sequence thrust (Leisette thrust; see Fig. 2).

Petit St. Bernard unit

The Petit St. Bernard unit was originally, given its present-day structural position, ascribed to the Subbriançonnais palaeogeographical domain (Elter and Elter 1957) and later regarded 
as a unit of uncertain palaeogeographical origin by Antoine et al. (1992). The Petit St. Bernard unit is composed of a very incomplete stratigraphic succession that particularly lacks the sediments of the Valais trilogy (Fig. 4). The unit essentially consists of a thick series of Liassic calcschists that differs from the more purely calcareous facies typical for the Moûtiers unit. This thick succession of calcschists possibly indicates deposition in a fault-bounded basin. This facies and the presence of Late Triassic evaporites are characteristic for the Subbriançonnais found further to the SW (Grand Moëndaz area; Barbier 1948; Ceriani and Schmid 2004). As will be discussed, the Valais ocean opened later, i.e. during the Cretaceous, and obliquely to pre-existing palaeogeographical domains like the Subbriançonnais domain that came into being earlier, i.e. during Early Jurassic rifting along the future continental margins of the Piemont-Liguria ocean, and that are now found near the ocean-continent transition formed during the opening of the younger Valais ocean.

We attribute the Petit St. Bernard unit to the Valais units for a number of reasons, the most important ones being (1) the structural overprint and particularly the metamorphic history (high-pressure overprint) of this unit are the same as that of the other Valais units (see Fig. 7 discussed later) and (2) the retrodeformation of post-nappe folding (D2), also discussed below, reveals an original tectonic position of the Petit St. Bernard unit in the footwall of the Versoyen unit (D1-thrusting). Both the Petit St. Bernard unit and the Roc de l'Enfer unit were emplaced onto the Versoyen only during late-D2 out-of-sequence thrusting (see the Col des Rousses and Leisette thrusts in Fig. 2).
Internal Valais unit (Versoyen unit)

While Elter and Elter (1957) originally confined the term Versoyen to a zone consisting of extensive and numerous masses of ophiolites, accompanied by black fine-grained detrital sediments, we also include those post-rift sediments that stratigraphically cover the Versoyen in the sense of Elter and Elter (1957), as well as the remnants of extensional allochthons formed by granitoids and gabbros (Punta Rossa Complex of Fig. 2) into our Versoyen unit. As will be discussed later, the Internal Valais unit represents an ocean-continent (Valais ocean) transition and is stratigraphically covered by the same Valais trilogy also found in the adjacent units of the External Valais units (Jeanbourquin 1995; Fügenschuh et al. 1999). The older pre- and syn-rift lithologies that characterize the Versoyen, as discussed below in more detail, dramatically differ from those found in all the External Valais units. They consist of (see Fig. 2) the following: (1) the Punta Rossa Complex; (2) the Brèches du Collet des Rousses Formation; and (3) a lithological association that predominantly consists of serpentinites and mafic sills that intrude black schists (Complexe Antéflysch Formation, see below).

\section{Stratigraphy and lithological compositions}

Figure 3 provides a palaeogeographical overview of stratigraphic successions that are characteristic for the main

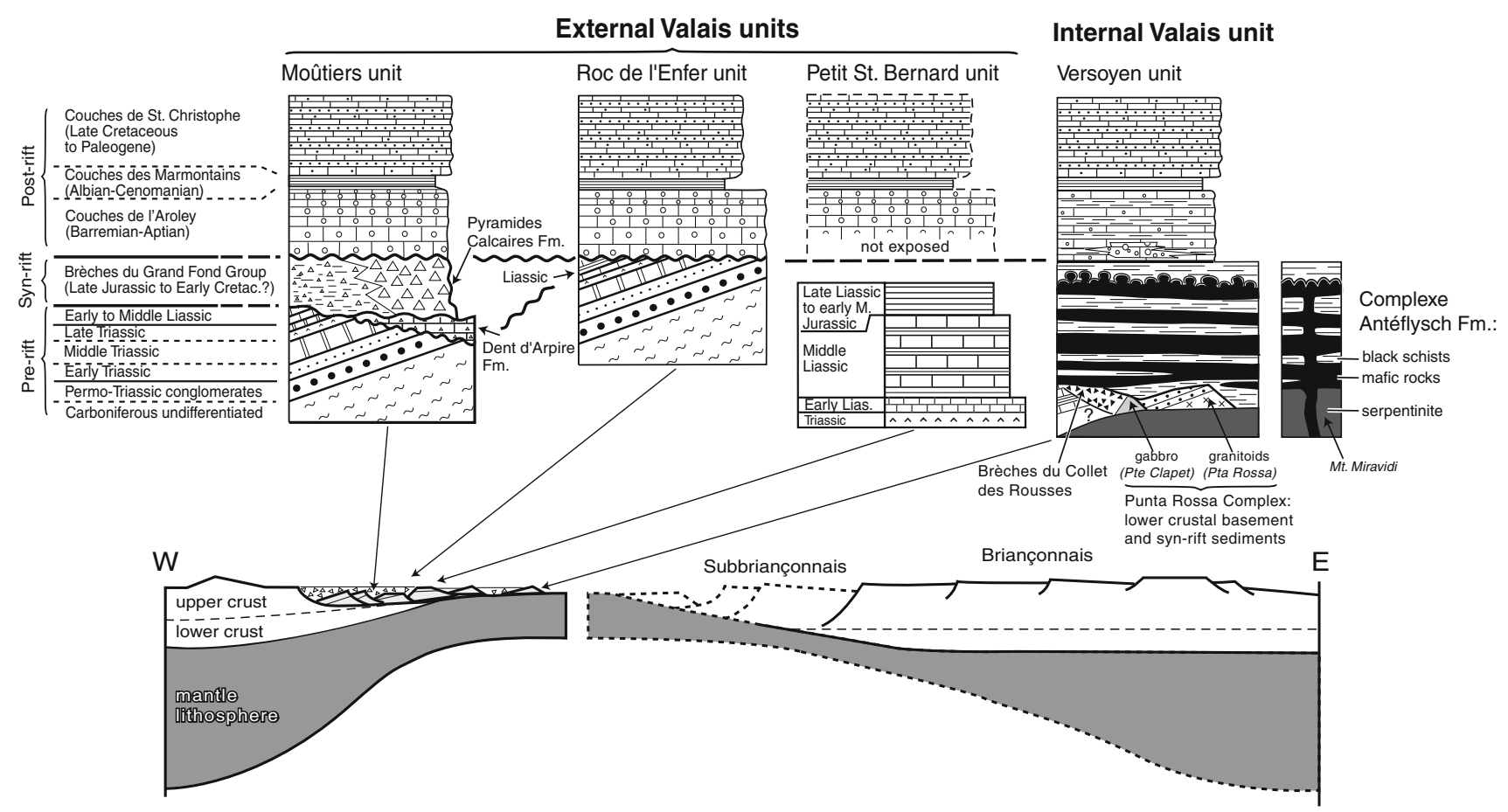

Fig. 3 Schematic stratigraphic columns of the Valais units and proposed palaeotectonic setting (after Antoine 1971; Antoine et al. 1992; Fügenschuh et al. 1999; Loprieno 2001) 
units attributed to the Valais domain, which departs in some details from that previously published by Fügenschuh et al. (1999). Drawing of the sketch, which places the profiles into their larger-scale palaeogeographical context, is guided by two main hypotheses based on our field data: (1) we assume that the rifting leading to the opening of the Valais oceanic realm by oblique spreading post-dates an earlier rifting event related to the opening of the Piemont-Liguria branch of Alpine Tethys, following the ideas proposed by Frisch (1979) and Stampfli (1993). Thereby an older rifted continental margin related to the mid-Jurassic break-up of the Piemont-Liguria ocean, i.e. the Briançonnais-Subbriançonnais domain, was affected by a second pulse of rifting related to the opening of the Valais ocean within the Subbriançonnais realm, which occurred during Early Cretaceous times. The term post-rift sediments refers to the second rifting event since the break-up unconformity is of Early Cretaceous age, pre-dating the deposition of the oldest postrift sediments (Aroley Formation) in Barremian-Aptian times. The age of the rarely preserved syn-rift sediments (Early Jurassic vs. Early Cretaceous) is uncertain, however, as will be discussed later. (2) Due to a higher density that led to complete subduction of large parts of the Valais domain, we assume a very poor preservation potential of the Valais oceanic domain in the present-day nappe stack. Thereby the External Valais units would represent the southeastern margin of the European continent that, in our area, also includes a part of the Subbriançonnais domain (pre-rift sediments of the External Valais units), while the Internal Valais unit would include series that represent the ocean-continent transition. Only small slivers of the Valais oceanic lithosphere are preserved in the present-day nappe stack within our area and elsewhere in the Valais units of the Swiss Alps (e.g. Jeanbourquin and Burri 1991; Steinmann and Stille 1999). The rest of the Valais oceanic lithosphere and the transition into the southeasterly adjacent Briançonnais microcontinent has been subducted and/or omitted by normal faulting; it is totally missing within the nappe pile at the earth's surface, except perhaps for the Pierre Avoi slice found in adjacent Switzerland (Bagnoud et al. 1998).

Pre-rift sediments of the External Valais units

Figure 4 summarizes the stratigraphy found in the Moûtiers unit, with a palaeo-karst surface marking the end of the pre-rift sequence in those rare places that preserve the syn-rift sequences (column shown for the Moûtiers unit in Fig. 3). Note that in most places within the Moûtiers unit, the post-rift Valais trilogy rests unconformably on older rocks (like in the Roc de l'Enfer unit; see Fig. 3). The

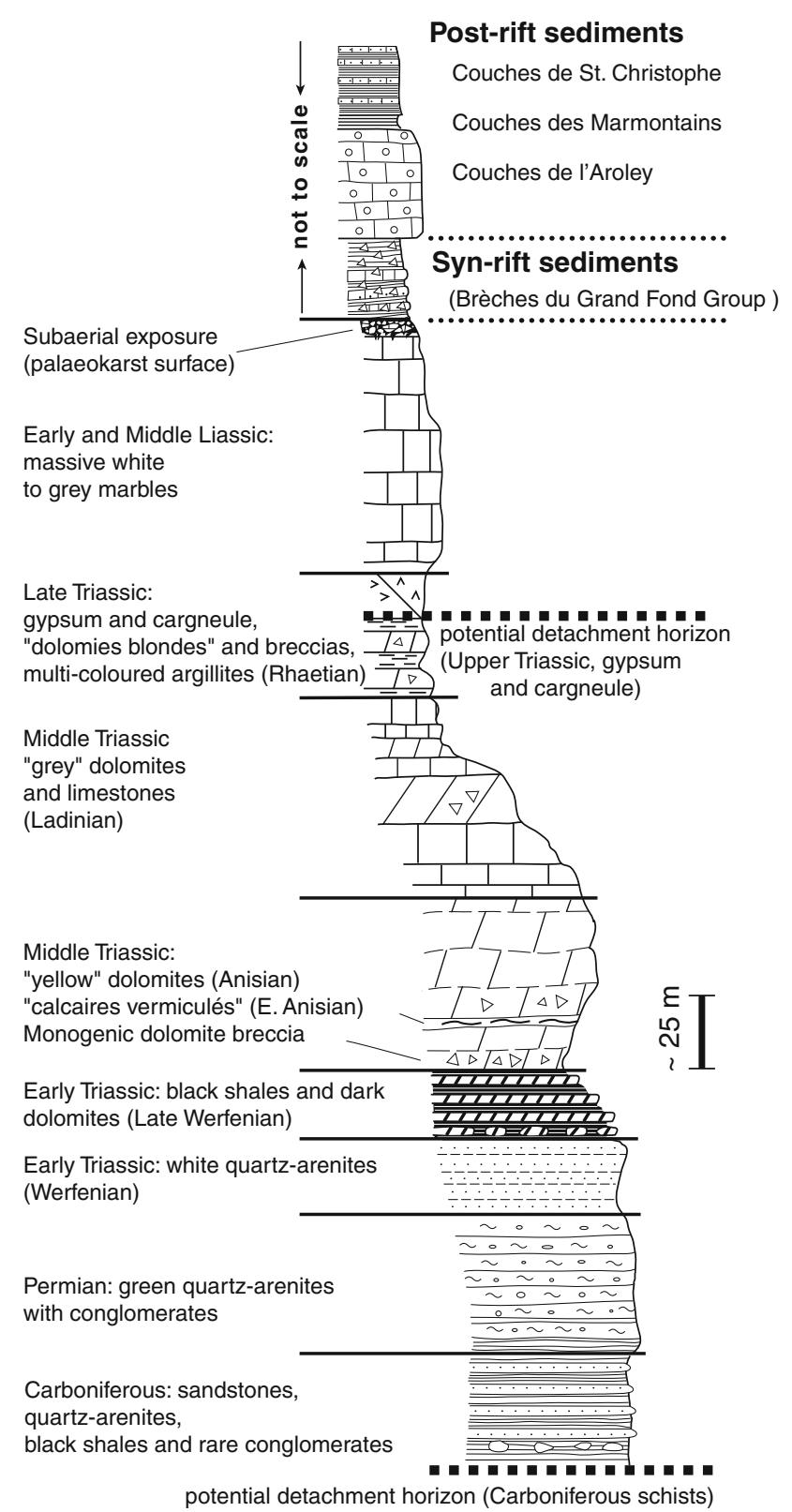

Fig. 4 Schematic stratigraphic section of the Moûtiers unit (after Antoine 1971; Antoine et al. 1992; Fudral 1973, 1998)

unconformity locally cuts down into Permian sediments (and even into the Palaeozoic basement, as mapped near Môutiers in an anticline at Hautecour southwest of our area), pointing to substantial relief caused by rift-shoulder uplift and leading to massive erosion in pre-Barremian times. This erosion also eliminated much of the syn-rift sediments whose probable age will be discussed below. The Roc de l'Enfer unit is dominated by the Permian age pre-rift formations, while syn-rift sediments are totally missing. In the External Valais units in general the prerift sequence, up to the relatively thick middle Triassic 
beds, has great similarities to that found in parts of the adjacent Zone Houillère. The Late Triassic to Early Jurassic sediments have a facies similar to that found in the Subbriançonnais outcropping further to the SSW along strike, i.e. south of Moûtiers (Grand Moëndaz area; Barbier 1948).

The Late Triassic evaporites form an important detachment horizon that served for the décollement of the Petit St. Bernard unit. Apart from occasional cargneule and gypsum sometimes associated with Late Triassic dolomite ("dolomies blondes") and black schists with Avicula contorta of Rhaetian age (Antoine 1971), the Petit St. Bernard unit is almost exclusively made up of Jurassic deposits. The Early Jurassic of the Petit St. Bernard unit starts with cherty limestones, followed by a 800 - to 1,000 -m-thick sequence of calcschists (Antoine 1971), interpreted to be of middle Early Jurassic age because of the occurrence of belemnites (Franchi 1900; Antoine 1971). The youngest rocks are black schists whose attribution to the late Early Jurassic (Antoine et al. 1992) is only based on lithostratigraphic evidence. These rocks acted as a décollement horizon along which all the younger sediments, i.e. mostly post-rift deposits, were detached during nappe stacking (Fig. 4).

Magmatic and sedimentary rocks of the Internal Valais unit (Versoyen unit) pre-dating the transgression of the Valais trilogy

Our analysis (see Fig. 4 discussed later), as well as that of many other workers in the area (i.e. Debelmas et al. 1991; Fudral 1998), confirmed the observations of Antoine (1971) who recognized the stratigraphic contact of the younger Valais trilogy with a sequence of basaltic sills that are gabbroic in the centre ("Roches Vertes du Versoyen") and that intrude the black schists. Tectonically emplaced slices of serpentinite are also found; the largest slice crops out at Mont Miravidi (Fig. 2). This series occasionally also contains pillow lava and/or volcanic breccia, and in its younger parts, carbonaceous schists referred to as "schistes gris" by Loubat (1968) and Antoine (1971). Following Loprieno (2001), we use the term Complexe Antéflysch Formation (as mapped in Fig. 2) for this association of magmatic and sedimentary rocks, a term introduced by Antoine (1971) for the rocks that pre-date the Valais trilogy in the areas he considered as being part of his RoignaisVersoyen unit. This implies that Antoine (1971) used the term Complexe Antéflysch also for some calcschists found in our Moûtiers unit.

The pillow basalts and the cores of sills of the Complexe Antéflysch Formation have flat REE patterns characteristic of N-MORB and T-MORB, while the geochemistry of the sill margins provides evidence for contamination caused by the intrusion of hot mafic magmas into unconsolidated sediments rich in water (Mugnier et al. 2008). This confirms earlier observations made by Loubat (1984), Loubat and Delaloye (1984) and Schürch (1987) in the area. Note that Kelts (1981) and Einsele (1985) drew attention to the fact that such sill-sediment complexes are presently found in the Gulf of California and that they may also occur in orogenic belts where they indicate high sedimentation rates during spreading within narrow oceanic pull-apart basins. In his pioneering article, Kelts (1981) proposed to use the Gulf of California as an actualistic example for the North Penninic Valais trough of which the Versoyen in our area is a part.

The black schists that are intercalated with the sills comprise various types of argillites and siltstones that occasionally contain thin carbonaceous or quartzarenitic lens-shaped layers. The mineralogical composition of the detritus consists of white mica, quartz, calcite, clay minerals (now chlorite), tourmaline, oxides and organic material. Antoine (1971), based on geochemical analyses, proposed that the sediments of the Complexe Antéflysch Formation formed by erosion of a subaerial domain located far from the site of deposition. Up-sequence the black schists show a gradual trend towards more carbonaceous schists ("schistes gris" of Loubat 1968; Antoine 1971). A gradual transition from the sedimentation of the schists of the Complexe Antéflysch Formation to that of the calcareous Aroley Formation is also evident from the detailed profile presented in Fig. 5. Hence, the arguments for a stratigraphic contact to the Aroley Formation are beyond any doubt also for all previous authors, except Masson et al. (2008). The Complexe Antéflysch Formation predates the BarremianAptian (Aroley Formation) and post-dates conglomerates of presumably post-Early Jurassic age described below (Brèches du Collet des Rousses Formation of Fig. 2). In accordance with the view of Antoine (1971), we assign an Early Cretaceous age to this formation, on the basis of arguments presented in the discussion of the data. No radiometric ages could be obtained so far for the mafic sills.

As observed by previous workers (e.g. Elter and Elter 1965; Loubat 1968; Dalla Torre 1998; Loprieno 2001), the Complexe Antéflysch Formation stratigraphically overlies the Brèches du Collet des Rousses Formation in many places (Figs. 2, 3). Pieces of this sedimentary formation occur as xenoliths within the immediately adjacent basalts (Loubat 1975; Schürch 1987; Dalla Torre 1998). The "brèches" du Collet des Rousses are in fact matrix-supported conglomerates with well-rounded clasts that mostly consist of Early Jurassic limestone pebbles embedded in a belemnite-bearing matrix of calcschists. This is why this formation was given a mid-Jurassic age 


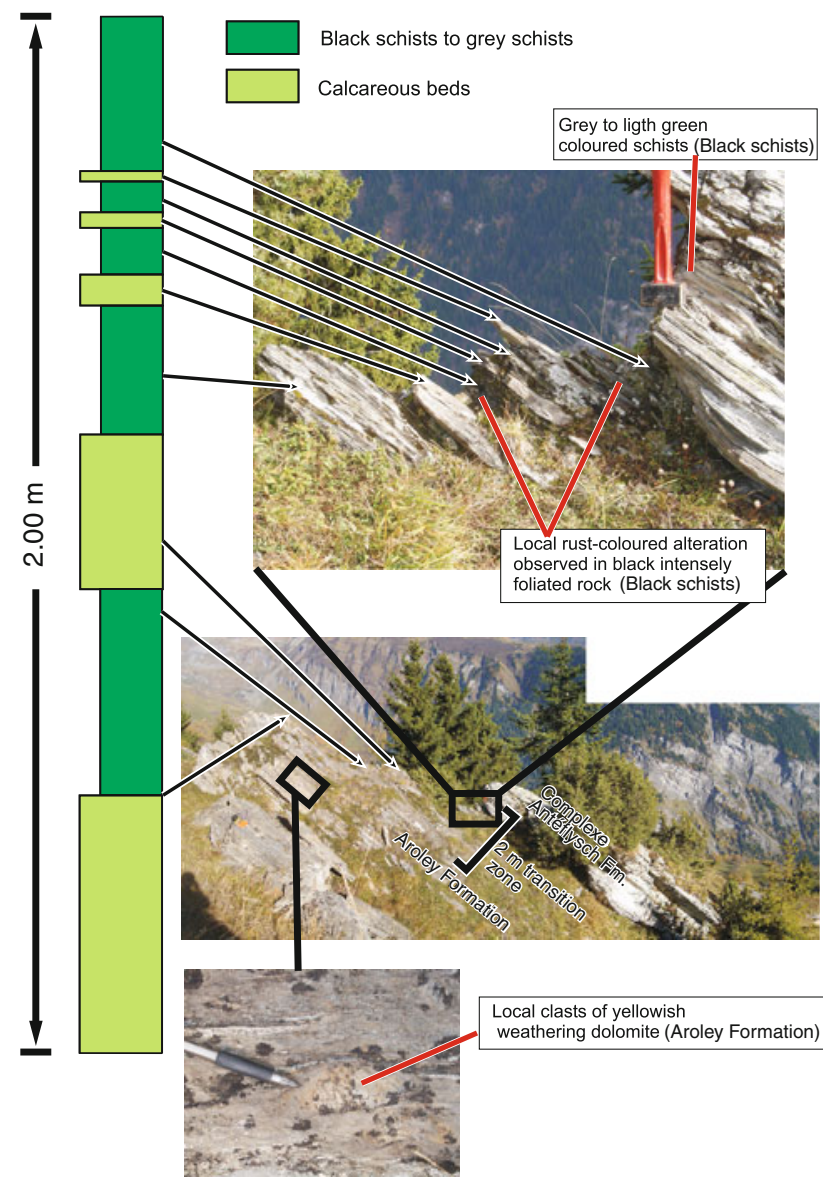

Fig. 5 Detailed profile of the transition zone between de Complexe Antéflysch Formation and the Aroley Formation, evidencing the stratigraphic nature of this contact. The section, taken from the Versoyen unit some $150 \mathrm{~m}$ NE from Les Essies locality (French coordinates $945^{\prime} 375 / 2^{\prime} 081^{\prime} 525$ ), is overturned. Note that the same section also contains mafic sills some $10 \mathrm{~m}$ further up-section (stratigraphically down-section)

by Antoine (1971). However, the real age of this postLiassic and pre-Barremian-Aptian formation remains unknown.

The immediate stratigraphic base of the Brèches du Collet des Rousses Formation is missing due to a presently overturned late-D1-thrust contact at the base of the Versoyen marked by evaporitic horizons (Fig. 2). Laterally, along the same thrust it is the Punta Rossa Complex that forms the base of the overturned Versoyen in the area of the Punta Rossa and the Aiguille du Clapet (Fig. 2). This is the reason for interpreting the Brèches du Collet des Rousses Formation as a fault-bounded synrift formation, which pre-dates the Complexe Antéflysch Formation (see schematic stratigraphic column for the Versoyen in Fig. 3). In fact, the entire Punta Rossa Complex, of which the Brèches du Collet des Rousses Formation is a part (Fig. 3), pre-dates the
Complexe Antéflysch Formation and is of crucial importance regarding the controversy about the age and significance of the basalts of the Complexe Anteflysch Formation.

Other lithologies that are part of the Punta Rossa Complex are quartzo-feldspatic gneisses in granulite facies (?) mapped in the Punta Rossa area and referred to as leptynites by Antoine (1971) because of their porphyroblastic microstructure. These are covered by siliciclastic synrift sediments including conglomerates reworking this basement and grading upwards into the black schists of the Complexe Anteflysch Formation (Dalla Torre 1998). This provides clear evidence that this quartzo-feldspatic basement here forms the stratigraphic base of the Complexe Antéflysch Formation. Recently, the intrusion age of these Punta Rossa granitoids was dated as Permian (267 $\pm 1 \mathrm{Ma}$; concordia age determined by SHRIMP U-Pb dating of zoned zircons by Beltrando et al. 2007). Interestingly, ortho- and clinopyroxene-bearing serpentinites, ophicarbonates and gabbros are also found in the Punta Rossa area, spatially associated with the Punta Rossa granitoids and/or their immediate siliciclastic cover (see Dalla Torre 1998 for more details). While the gabbros could perhaps also be interpreted as manifestations of bi-modal magmatism of Permian age, the serpentinites and ophicarbonates argue for denudation of mantle rocks at the seafloor during Mesozoic rifting. Due to intense deformation in the area, it is hard to decide which of the contacts between serpentinites and granitoids are related to Alpine deformation and which formed during a rifting event that, according to our interpretation, led to the denudation of subcontinental mantle rocks at the sea floor.

The Aiguille du Clapet area exposes, apart from intercalated basalts and black schists attributed to the Complexe Antéflysch Formation, an association of various rock types that builds up most of the almost non-accessible Aiguille du Clapet peak and that we associate with the Punta Rossa Complex. This attribution is primarily based on the recent SHRIMP U-Pb dating of a leuco-gabbro as part of a layered magmatic sequence found at the base of the Aiguille du Clapet peak by Beltrando et al. (2007), which also yielded a Permian age $(272 \pm 2 \mathrm{Ma})$. This indicates bi-modal magmatism typical for Early Permian times and found in many other parts of the Alps that expose lower crustal rocks later exhumed near an ocean-continent transition (Sesia zone: Rubatto et al. 1999; Ivrea zone: Handy et al. 1999; Val Malenco area: Hermann et al. 1997; Engadine window: Froitzheim and Rubatto 1998; Manatschal et al. 2006). Hence, it appears that the Permian leuco-gabbros, together with the granitoids from the Punta Rossa area, are part of a basement that is older than the Complexe Antéflysch Formation and that predates the 
intrusion of the mafic dykes so typical for the Versoyen. The latter must be younger since they post-date both the post-Early Jurassic Brèches du Collet des Rousses Formation and the Permian Punta Rossa Complex. Note, however, that Schärer et al. (2000) dated other leuco-gabbros from the Aiguille du Clapet area with $309 \pm 6 \mathrm{Ma}$, while Masson et al. (2008) obtained an even older age of $337 \pm 4.1 \mathrm{Ma}$. We will comment on these Carboniferous ages that, according to the above-mentioned authors, prove a Variscan age of the "Versoyen ophiolites", including the Complexe Antéflysch Formation, in the "Discussion" section.

In summary, the substratum found below the Complexe Antéflysch Formation in the Internal Valais unit does appear to represent not only truly oceanic pieces of lithosphere. Instead, we find a sequence that is typical for the most distal part of a continental margin adjacent to denudated subcontinental mantle (serpentinites) emplaced during the formation of oceanic lithosphere within the narrow Valais ocean. It is the serpentinites, like those found near Mont Miravidi and within the Punta Rossa Complex, that play a key role for our interpretation discussed further after the presentation of the structural data.

Syn-rift sediments of the External Valais units

The so-called Brèches du Grand Fond (Antoine et al. 1972; Fudral 1998) are bounded by two unconformities: one at the base that post-dates Middle Liassic limestones and one at the top that pre-dates the Barremian-age base of the post-rift sediments (Aroley Formation). In general, the Brèches du Grand Fond are characterized by clasts consisting of all the lithologies found in the pre-rift sediments (Carboniferous to Middle Liassic) and, additionally, crystalline basement rocks. In the area of the External Valais units, perennial background sediments are hardly noticed during this large time interval, which must have been characterized by erosion as a consequence of syn-rift faulting and tilting of pre-mid-Jurassic formations. Moreover, these syn-rift sediments are totally lacking in most areas of the External Valais units. Hence, substantial erosion must also have occurred during and after the final stages of rifting, but before the deposition of the base of the post-rift sediments (Aroley Formation) above an angular unconformity representing a break-up unconformity (Fügenschuh et al. 1999). A detailed analysis of the syn-rift deposits, referred to as Brèches du Grand Fond Group, is found in Loprieno (2001). Two distinct lithostratigraphic formations are locally divided by yet another angular unconformity (Fig. 3): the older Dent d'Arpire Formation discordantly overlies Permian to Middle Triassic pre-rift sediments, while the younger
Pyramides Calcaires Formation either unconformably overlies the Dent d'Arpire Formation (like in the area of the Aiguille du Grand Fond, Fig. 2), or alternatively, directly rests on Early- to Mid-Liassic pre-rift sediments that are topped by palaeo-karst (such as in the high Vallée des Glaciers and Pyramides Calcaires areas, Fig. 2).

The Dent d'Arpire Formation is only preserved near the Aiguille du Grand Fond and is characterized by a coarse clast-supported conglomerate with an impure schistose light-coloured matrix at the base and by a matrix-supported conglomerate with a pure, massive, light grey to bluish limestone matrix at the top of the formation. A new ammonite finding within the lower part of the Dent d'Arpire Formation (Loprieno 2001) indicates a Toarcian age for the base of this syn-rift formation; therefore, this syn-rift formation must be related to the rifting that led to the opening of the older Piemont-Liguria ocean. The top surface of the formation is irregular due to the erosion preceding or accompanying the deposition of the younger Pyramides Calcaires Formation that predominantly consists of brownish calcschists. Only in the Aiguille du Grand Fond area is a characteristic facies preserved, which is made up by a chaotic sequence of unbedded gravity-flow deposits (Combe de la Nova section; Loprieno 2001). In this sequence, the size of the unsorted clasts and blocks ranges from a few centimetres up to $30 \mathrm{~m}$. Some of these clasts are large well-rounded boulders of conglomerates resulting from the reworking of the lower Dent d'Arpire Formation. Previous work in the Combe de la Nova region referred to the Dent d'Arpire and the Pyramides Calcaires formations as "ensemble conglomératique inférieur et supérieur” (Antoine et al. 1972; Fudral 1973).

The facies of the syn-rift sediments is very different in the area of the Vallée des Glaciers where more distal and fine-grained debris-flow deposits predominate. There, the Dent d'Arpire Formation is totally missing and replaced by a palaeo-karst surface. The Pyramides Calcaires Formation consists of brownish calcschists, but also contains layers of black shales, fine calcareous sandstone with quartz and beds consisting of fine conglomerates in which Middle Triassic dolomite clasts are predominant. The rhythmic bedding and detrital nature of the rock types suggests that the Pyramides Calcaires Formation here represents a predominantly turbiditic series. Note that the Pyramides Calcaires Formation in the Vallée des Glaciers was described as "Complexe Antéflysch" by previous workers and attributed to their "Roignais-Versoyen unit" (Antoine 1971; Antoine et al. 1972), while we attribute it to the External Valais units, i.e. the Moûtiers unit. The Pyramides Calcaires Formation in the Vallée des Glaciers forms a continuous narrow band, which can be followed from 
Les Chapieux all the way to the Pyramides Calcaires. Interestingly, some of the calcschists of the Pyramides Calcaires Formation are very similar to carbonaceous schists that occur in the youngest parts of the Complexe Antéflysch Formation referred to as to "schistes gris" by Loubat (1968) and Antoine (1971). Hence, these latter possibly represent a very distal facies of the Pyramides Calcaires Formation in the Vallée des Glaciers. Also, according to similar observations made in the Internal Valais units, the transition into the sediments of the postrift sequence starting with the Aroley Formation is gradual in the Vallée des Glaciers and lacks the angular unconformity that is so typical for the rest of the External Valais units. At the Pyramides Calcaires locality, the base of the Pyramides Calcaires Formation yielded Orbitolina sp., suggesting an Early Cretaceous age for the entire Pyramides Calcaires Formation at this locality (Elter 1954, confirmed by this study). This indicates that the deposition of the Pyramides Calcaires Formation in this particular area immediately pre-dates that of the Aroley Formation.

It is tentatively proposed that the Dent d'Arpire and Pyramides Calcaires formations were deposited during two distinct events of rifting affecting the External Valais units separated by an interval of erosion or non-deposition. The first rifting event must have been related to the opening of the Piemont-Liguria ocean given the Liassic age of the Dent d'Arpire Formation. The age of the younger Pyramides Calcaires Formation is unconstrained in most places due to the lack of fossils, except for local findings of Orbitolina sp., pointing to an Early Cretaceous age of at least parts of this formation. This, together with the close lithological similarities of some of the calcschists of the Pyramides Calcaires Formation with the carbonaceous schists that occur in the youngest parts of the Complexe Antéflysch Formation, suggests that the Pyramides Calcaires Formation is made up of syn-rift deposits related to the Valais rifting and may partly be coeval with the deposition of the Complexe Antéflysch in the Internal Valais unit.

Post-rift sediments of the External and Internal Valais units (Valais trilogy)

The three mappable formations of the Valais trilogy (from bottom to top: Couches de l'Aroley, Couches des Marmontains and Couches de St. Christophe, defined by Trümpy 1951, 1954) are interpreted to represent a post-rift sequence because they were deposited on oceanic to transitional lithosphere (Internal Valais unit, see Fig. 5) and continental lithosphere (External Valais units) alike. The relative age of the three formations is well-established and undisputed, except for the differing view expressed by Masson et al. (2008), since the oldest Aroley Formation directly lies on the older Mesozoic cover of the External Valais units above an angular unconformity (Fig. 3). The biostratigraphic age of the three formations, however, is only partly defined due to the paucity of fossils.

The sediments of the Aroley Formation of the External Valais units mostly consist of massive conglomerates with a grey to blue calcareous matrix, interpreted as submarine mass flow deposits (Lomas 1992) interbedded with a few and rather thin shale layers. The clasts are mostly derived from Carboniferous to Early Jurassic lithologies but also include pre-Carboniferous micaschists and granite. Sedimentation starts with thick beds of generally clast-supported coarse conglomerates without size sorting. An upward thinning and fining trend is observed, associated with a trend towards matrix-supported fabrics.

In the case of the Internal Valais unit, the base of the Aroley Formation is occasionally ill defined (Fig. 5); sedimentation of the Aroley Formation followed that of schists of the Complexe Antéflysch Formation without any angular unconformity. Moreover, the Aroley Formation of the Internal Valais unit is dominated by a regular alternation of calcschists with calcarenitic and argillaceous beds. Isolated conglomeratic beds are found near the base but never at the top of the formation. In a few places, massive grey limestone was also observed. Also, the Aroley Formation of the Internal Valais unit is characterized by an upward fining trend.

A thinning and fining trend is also found in a lateral direction, i.e. when going from the External Valais units towards the Internal Valais unit. As recognized by Antoine (1971), this indicates a more distal depositional realm for the Internal Valais unit. Lomas (1992) infers a depositional system in which debris shed by a rapidly eroding source area to the west (External Valais units) were transported directly to relatively deep water (Internal Valais unit). All these points towards a systematic topographic gradient due to rift-induced flank uplift in the External Valais units, a gradient that persisted during the deposition of the Marmontains Formation.

The Aroley Formation was dated as Barremian-Aptian based on Orbitolina sp. by Trümpy (1954) in the Val Ferret in adjacent Switzerland. The same age was also proposed by Elter $(1951,1954)$ who discovered small fragments of Orbitolina sp. at the Pyramides Calcaires locality, immediately below the base of the Aroley Formation. Finally, Sodero (1968) found Orbitolina sp. and dasyclad algae in the "Couches de l'Aroley" in the Aosta Valley, along strike of the External Valais units of our area. Hence, we regard the evidence for a Barremian-Aptian age for the base of the "Couches de l'Aroley" as conclusive. Note, however, that this age was questioned by Antoine $(1965,1971)$ who discovered a pyritized specimen of Globotruncana lapparenti coronata, indicating a Turonian-Santonian age in 
sediments he believed to immediately underlie the Aroley Formation in an intensely deformed area. A Barremian to Aptian age for the Aroley Formation is additionally supported by its close lithostratigraphic similarities with its equivalent, the Tristelkalk Formation of Eastern Switzerland that was dated as Barremian to Early Aptian (Schwizer 1983). In the Tasna nappe of the Engadine window, the Tristelkalk Formation, overlying a series of dark shales, which are very similar to the Complexe Antéflysch, also seals an oceancontinent transition at the margin of the Valais ocean (Florineth and Froitzheim 1994).

The Marmontains Formation, although only a few tens of metres thick, represents a key-horizon for establishing the younging direction of the post-rift sequence and its substratum. The Marmontains Formation consists of a characteristic alternation of carbonate-free black shales and green or brownish quartz-arenites. A coarse conglomerate facies is occasionally found in the External Valais units, typically towards the top of the formation (Fudral 1973). This facies was referred to as the "Grès grossiers et conglomératiques" by Antoine et al. (1992). In the Internal Valais unit, however, the Marmontains Formation exclusively consists of black shales. Hence, also the Marmontains Formation shows a transition to a more distal facies towards the Internal Valais unit. The facies analogies of the Marmontains Formation with similar lithologies found in the Tasna, Falknis and Schams nappes of Eastern Switzerland, the so-called Gault with black shales rich in organic carbon, interbedded with "Oelquarzit" and "Plattensandstein" (Hesse 1973; Rück 1995; Florineth and Froitzheim 1994) are striking. Rück (1995) attributes these lithologies to the "mid"-Cretaceous anoxic event (Jenkyns 1980). In eastern Switzerland, Allemann (1957) dated the top of this formation to be of Cenomanian age.

The youngest formation of the Valais trilogy, the St. Christophe Formation is very thick (600-900 m according to Antoine 1971) and intensely folded, forming the bulk of the post-rift sediments. This monotonous alternation of calcareous-arenaceous strata and black marls and schists is interpreted as a turbiditic sequence and its facies is the same in both the Internal and External Valais units. The facies of the St. Christophe Formation is similar to that of some of the "Bündnerschiefer" of the Valais units in eastern Switzerland. The age of the St. Christophe Formation is unconstrained: sedimentation of these flysch-type turbidites presumably reaches from the Turonian all the way into the Palaeogene.

\section{Tectono-metamorphic evolution}

After peak-pressure conditions were reached during an earliest stage of the tectonometamorphic evolution, three major ductile deformation events (D1, D2 and D3; numbering is that used by Fügenschuh et al. 1999) visibly affected all Valais units within our area. The traces of related fold axial surfaces are shown in Fig. 6. A pre-D1event can be inferred only locally. An area at the NE edge of the area (Tête du Chargeur; Bucher 1999) was affected by post-D2 and pre-D3 ductile normal faulting (Pont Serrand ductile normal fault), reworking the former thrust of the Zone Houillère over the Valais units. A post-5 Ma D4 brittle normal fault (Fügenschuh et al. 1999) again reworks the same former thrust contact and defines the present-day boundary between Zone Houillère and Valais units everywhere within the area (Fig. 2).

\section{Metamorphic evolution}

The occurrences of HP index minerals in the Versoyen and the Petit St. Bernard unit (Fig. 7) are well established since the description of jadeite in granitoid lithologies at the Punta Rossa locality (Saliot 1979; Fudral 1998), omphacite-garnet-glaucophane in mafic rocks of the Complexe Antéflysch at the Aiguille du Clapet (Schürch 1987; Cannic et al. 1995), and of lawsonite-carpholite-chloritoid in metasediments of the Petit St. Bernard and Versoyen units (Goffé and Bousquet 1997).

Detailed observations of the mineralogy of HP minerals from metapelites clearly show that carpholite later became destabilized in favour of chloritoid and hence records an earlier stage of the metamorphic evolution (Goffé and Bousquet 1997). This indicates a poly-phase metamorphic evolution for the Internal Valais unit (Versoyen) and the internal most part of the External Valais units (Petit St. Bernard unit). Metamorphic conditions during a first stage, documented by occurrences of mineral assemblages with carpholite and lawsonite, have been estimated at $17 \mathrm{kbar}$ and temperatures around $375^{\circ} \mathrm{C}$ (Bousquet et al. 2002). In metapelites, a second HP stage is indicated by the growth of chloritoid at the expense of carpholite crystals, and additionally, by the findings of eclogitic rocks at the Aiguille du Clapet. During this second HP stage, temperatures ranged between 450 and $500^{\circ} \mathrm{C}$ at somewhat lower pressures around $15 \mathrm{kbar}$ (Cannic et al. 1995; Bousquet et al. 2002). This evolution is also documented by the replacement of lawsonite by clinozoisite-epidote-phengite in the presence of chlorite. The absence of kyanite or pyrophyllite defines the $\mathrm{P}-\mathrm{T}$ conditions above the equilibrium Lw $=\mathrm{Czo}-\mathrm{Ky}$ or $\operatorname{Prl}\left(\sim 400^{\circ} \mathrm{C}\right.$ at $8 \mathrm{kbar}$; Goffé and Bousquet 1997) during this second HP stage.

While the HP evolution of the Versoyen unit and the Petit St. Bernard unit is known since many years and was included in many models, the description of HP minerals in the External Valais units remained unrecognized until fairly recently (Goffé et al. 2004; Oberhänsli et al. 2004). 


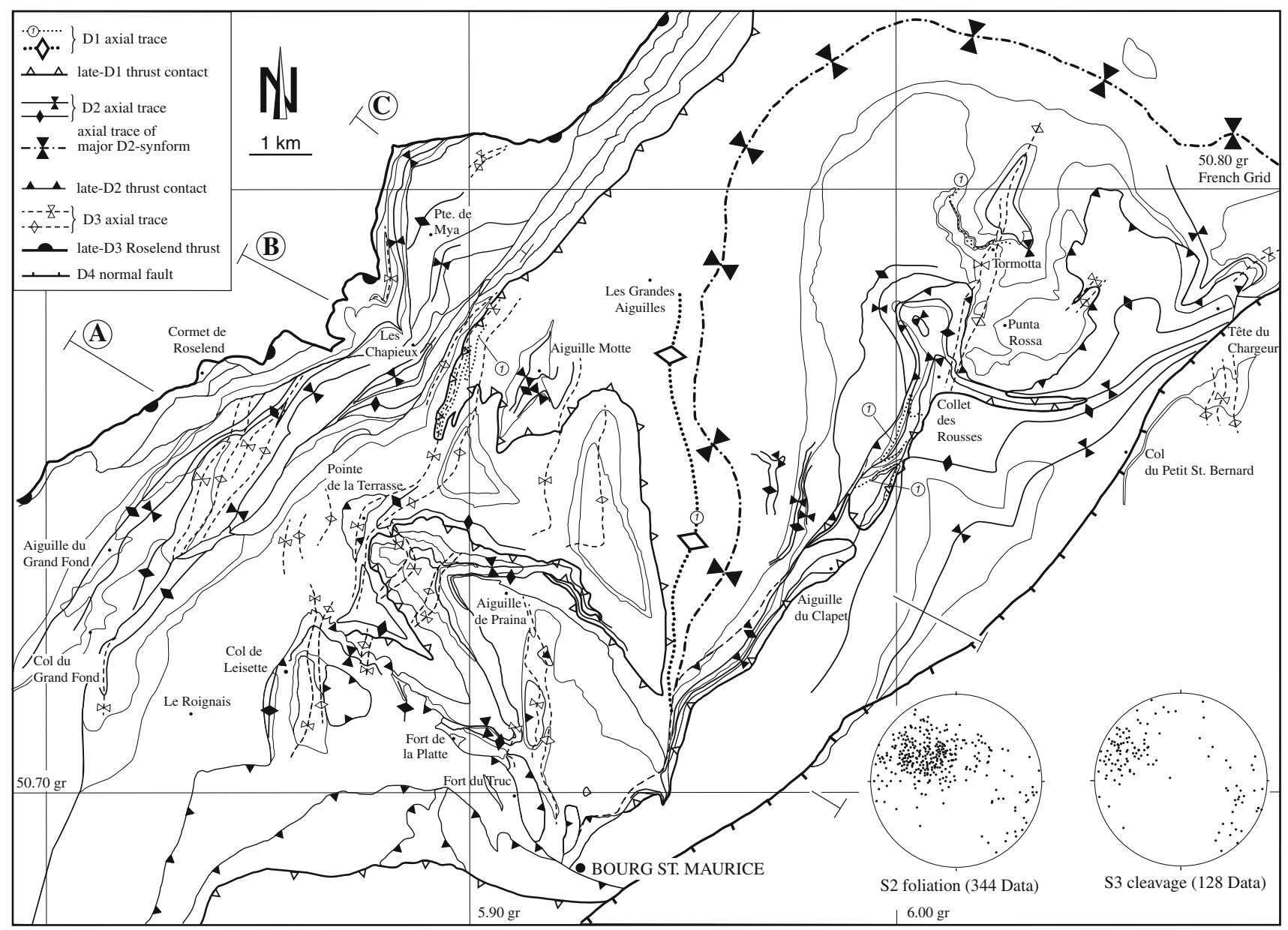

Fig. 6 Traces of the fold axial planes of F1, F2 and F3 folds within the Valais units and pole figures summarizing the orientation of S2 foliation and S3 cleavage planes; compare with Figs. 2 (tectonic map) and 13 (profiles indicated by traces labelled $A, B$ and $C$ ); from Loprieno (2001)
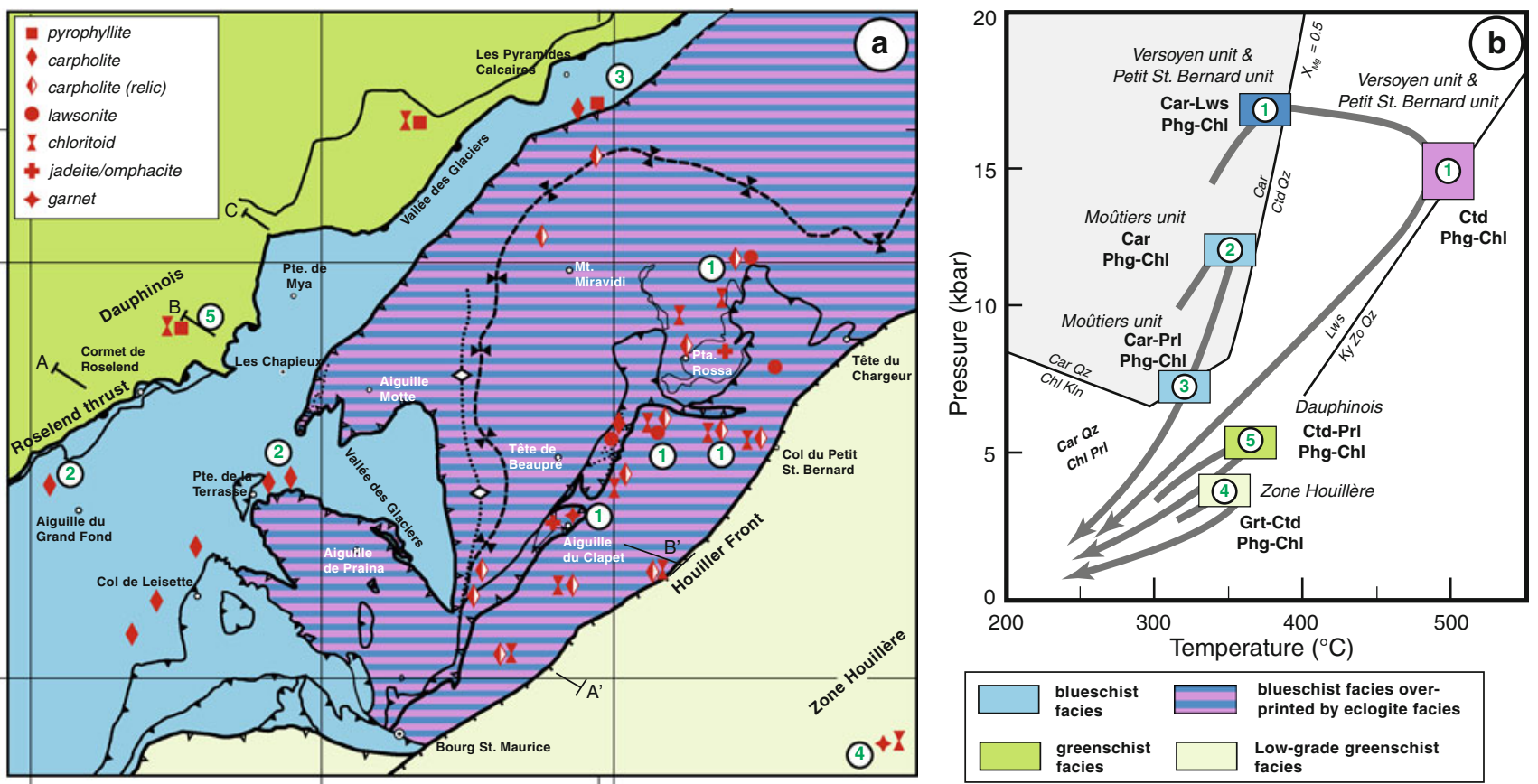

Fig. 7 a Metamorphic map and index minerals and b P-T-paths for selected samples whose location is indicated in a 
HP metamorphism in this zone is characterized by newly discovered abundant occurrences of well-preserved carpholite crystals in different types of rocks (calcschist, breccia) (Fig. 7). The stability of carpholite-phengite-chlorite assemblages indicates pressures of 12-13 kbar for temperatures of about $350^{\circ} \mathrm{C}$ (see discussion in Oberhänsli et al. 2003). The retrograde evolution in the External Valais units led to the breakdown of carpholite to pyrophyllitechlorite assemblages, stable at $8 \mathrm{kbar}$ and $325^{\circ} \mathrm{C}$ (Fig. 7). In summary, and most importantly, it recently became clear that the entire Valais domain, including the External Valais units representing the distal European margin, reached at least blueschist-grade metamorphic conditions. In the Versoyen unit and the internal most External Valais unit (Petit St. Bernard unit), HP conditions are documented by relic carpholite and lawsonite occurrences (Goffé and Bousquet 1997). Well-preserved carpholite characterizes the rest of the External Valais units (Goffé et al. 2004).

The metamorphic evolution of the Versoyen and Petit St. Bernard units is unique in the Alps, in that a first HP stage characterized by very low temperature conditions $\left(17 \mathrm{kbar}, 350^{\circ} \mathrm{C}\right)$ was overprinted by eclogitic conditions $\left(15 \mathrm{kbar}, 500^{\circ} \mathrm{C}\right)$ during a second stage. Hence, decompression was associated with a considerable increase in temperature. In contrast, the metamorphic evolution of the External Valais units is characterized by cooling during decompression (Fig. 7).

\section{Pre-D1-deformation}

According to microstructural analysis in metapelites, peakpressure conditions were reached before the first schistosity $\mathrm{S} 1$ formed, since the first schistosity $\mathrm{S} 1$ is defined by chloritoid, i.e. a break down product of carpholite (Fügenschuh et al. 1999, their Fig. 6). Hence, D1 is only associated with the second stage of the metamorphic evolution associated with decompression and heating in the Internal Valais unit, and there must be a pre-D1-deformation event that is associated with the subduction and the shearing-off of the Valais units from their former crustal and mantle underpinnings. However, no direct record of this pre-D1-deformation is preserved by mesoscopic or microscopic structures.

\section{D1-deformation}

D1 is associated with a second stage of the metamorphic evolution linked to decompression and a considerable increase in temperature in the case of the Versoyen unit during the earliest stages of D1. The pervasive $\mathrm{S} 1$ foliation is recognizable within all the Valais units. S1 is generally sub-parallel to bedding, pointing to penetrative straining. Elongated quartz or calcite minerals and long axes of breccia components (in the Brèches du Grand Fond Group and in the Aroley Formation) form a stretching lineation (L1) within the S1 schistosity. Due to subsequent deformations, the orientations of the L1 lineations exhibit considerable scatter, but a general $\mathrm{N}-\mathrm{S}$ trend, oblique to the overall strike, is still discernable (Fig. 8a). This is mainly due to the fact that D2 fold axes are sub-parallel to L1; hence, intense D2 folding only had a minor effect in reorienting L1 (compare Fig. 8a, b). However, reorientation of the L1 lineation during D3 and towards a SE-NW strike is substantial in the NW areas close to the Roselend thrust, where D3-deformation is particularly intense due to F3 folding and thrusting (Fig. 8a). Rarely found F1 fold axes (Fig. 9) are oriented sub-parallel to L1, which indicates large non-coaxial strains during D1. Unfortunately, no shear sense indicators unambiguously associated with L1 could be observed. However, large-scale tectonic considerations discussed later indicate top-N shearing during D1.

Detailed mapping of the area by Loprieno (2001) allowed to trace the axial planes of major F1 large-scale folds (Fig. 2) based on the analysis of F2-facing directions discussed below. Retrodeformation of subsequent deformations, also discussed later, shows that D1 was associated with the main nappe-stacking event, when the Internal Valais unit (Versoyen unit) was thrust onto the External Valais units (Moûtiers unit and Petit St. Bernard unit).

While D1-deformation post-dated peak-pressure conditions, the temperature maximum was reached during the initial stages of D1, i.e. during the early stages of decompression associated with heating in the Versoyen and Petit St. Bernard units (Bousquet et al. 2002). In the more external parts of the Valais palaeogeographical domain (i.e. the Moûtiers and Roc de l'Enfer units), however, the S1 foliation formed under greenschist-facies metamorphic conditions (Gely and Bassias 1990).

\section{D2-deformation}

D2-deformation is predominantly characterized by intense folding of D1-thrusts, the most prominent feature being a regional scale F2 fold, the Versoye synform (Fig. 2). Major D2-thrusts that we refer to as "late-D2-thrusts" formed as a result of progressive deformation, i.e. late during D2. In the internal parts of the Valais units, and only in a purely geometrical sense, these thrusts post-date previously formed F2 axial planes. Geometrically speaking, the largescale structure of the area is controlled by D2-deformation.

The S2 schistosity, often a crenulation cleavage, is generally less pervasively developed compared to S1. Spaced $(1-5 \mathrm{~mm})$ crenulation cleavage is typically developed in the hinges of F2 folds of Mesozoic pelitic and calcpelitic rocks (Fig. 10a) where phyllosilicates are missing; S1 remains the dominant foliation in the hinge areas. In the 

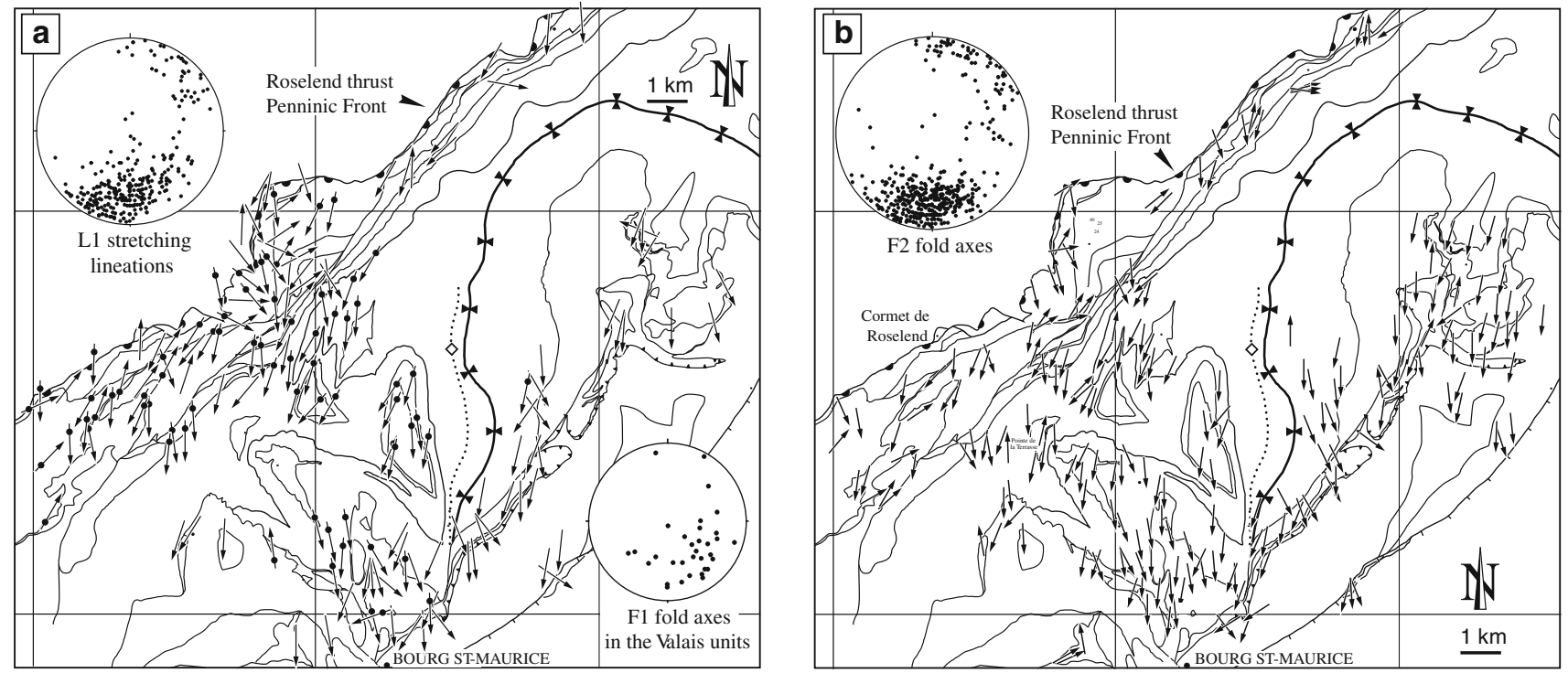

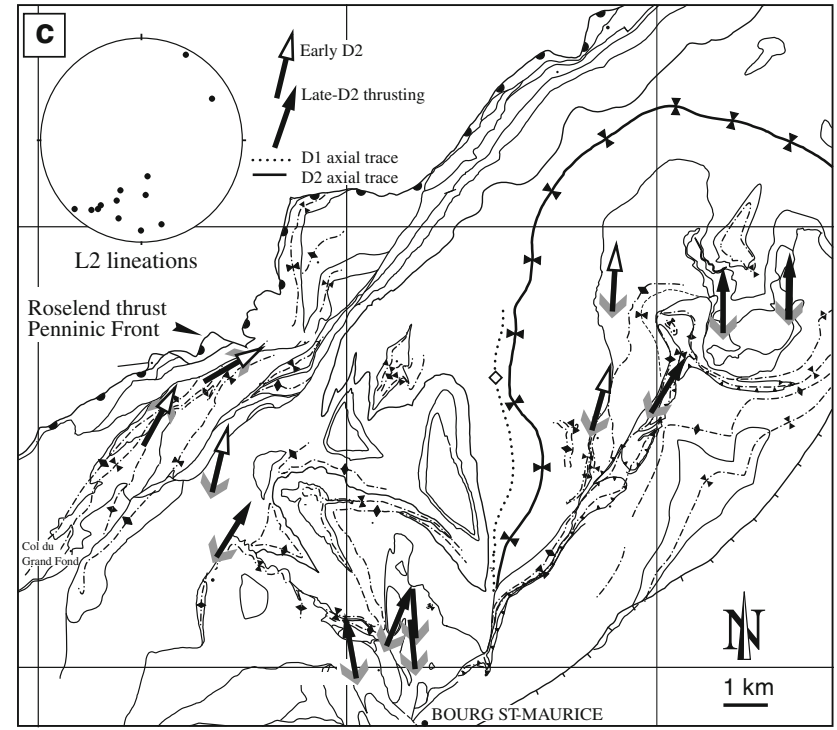

Fig. 8 Linear fabrics within the working area in map and pole figure representation. a Azimuth and dip of L1 stretching lineations; mineral lineations interpreted as stretching lineations (simple arrow); long axes of breccia components (arrow with solid dot); $\mathbf{b}$ azimuth and dip of second phase fold axes in the Valais units; $\mathbf{c}$ transport directions

F2 fold limbs, on the other hand, S2 is usually sub-parallel to both $\mathrm{S} 1$ and bedding (Fig. 10b).

S2 dominantly dips towards E and ESE (pole figure in Fig. 5). The dip generally increases from about $30^{\circ}-40^{\circ}$ in the $\mathrm{E}$ and $\mathrm{SE}$ to values between $50^{\circ}$ and $80^{\circ}$ in the $\mathrm{W}$ and NW part of the study area. This steepening of the S2 schistosity towards NW is due to overprinting by F3 folds characterized by steep axial planes. The intensity of D3 strain increases when approaching the late-D3 Roselend thrust located at the NW edge of the Valais units.

L2 stretching lineations definitely associated with the S2 cleavage could only occasionally be observed; they are

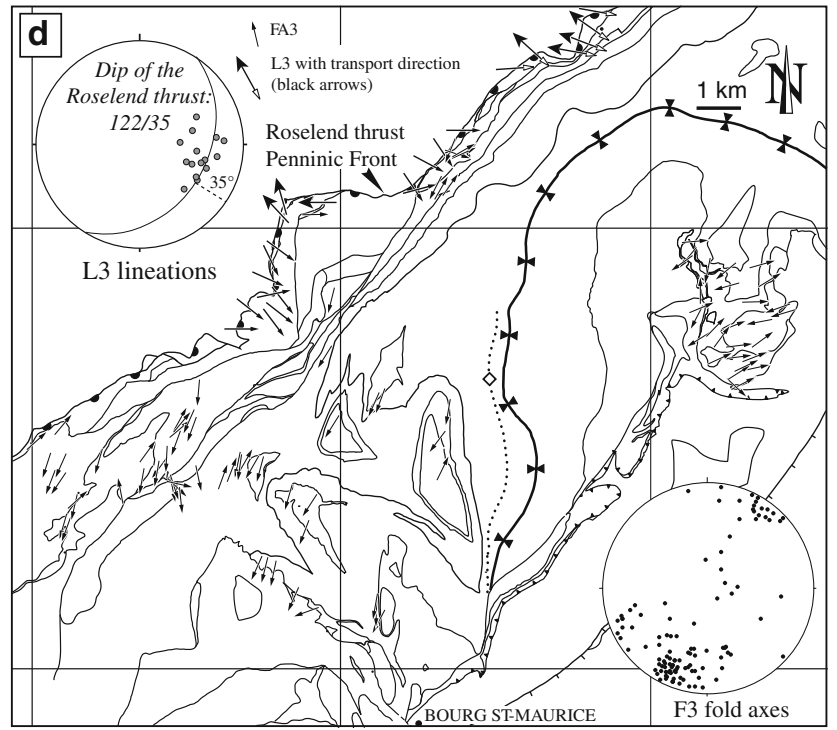

during D2 inferred from sense of shear criteria; grey arrows point to the sample locality and indicate the dip direction of the lineation, black arrows indicate sense of movement; d D3 fold axes (small arrow heads) and L3 stretching lineations (bold arrow heads) unit; pole figure only shows the L3 stretching lineations

mostly observed in mylonites related to late-D2-thrusting and will be described later. When S1/S2 overprinting criteria were not observable, a definite attribution of the stretching lineation and associated top-N shearing to either D1- or D2-deformation was impossible. Since the D1strain is larger in general, the stretching lineations were mostly ascribed to D1.

F2 similar folds are recognized on a metric (Fig. 10b) scale. However, up to kilometre-scale parasitic F2 folds to the main Versoye D2-synform refolding the entire nappe stack derived from the Valais palaeogeographical domain do also occur and will be discussed later. Dominantly, 
Fig. 9 Photograph and line drawing of F1 small-scale folds overprinted by D2 folds in the St. Christophe Formation of the Versoyen unit (=Internal Valais unit); Tête de Beaupré area (French coordinates $949^{\prime} 150 / 2^{\prime} 085^{\prime} 750$ )
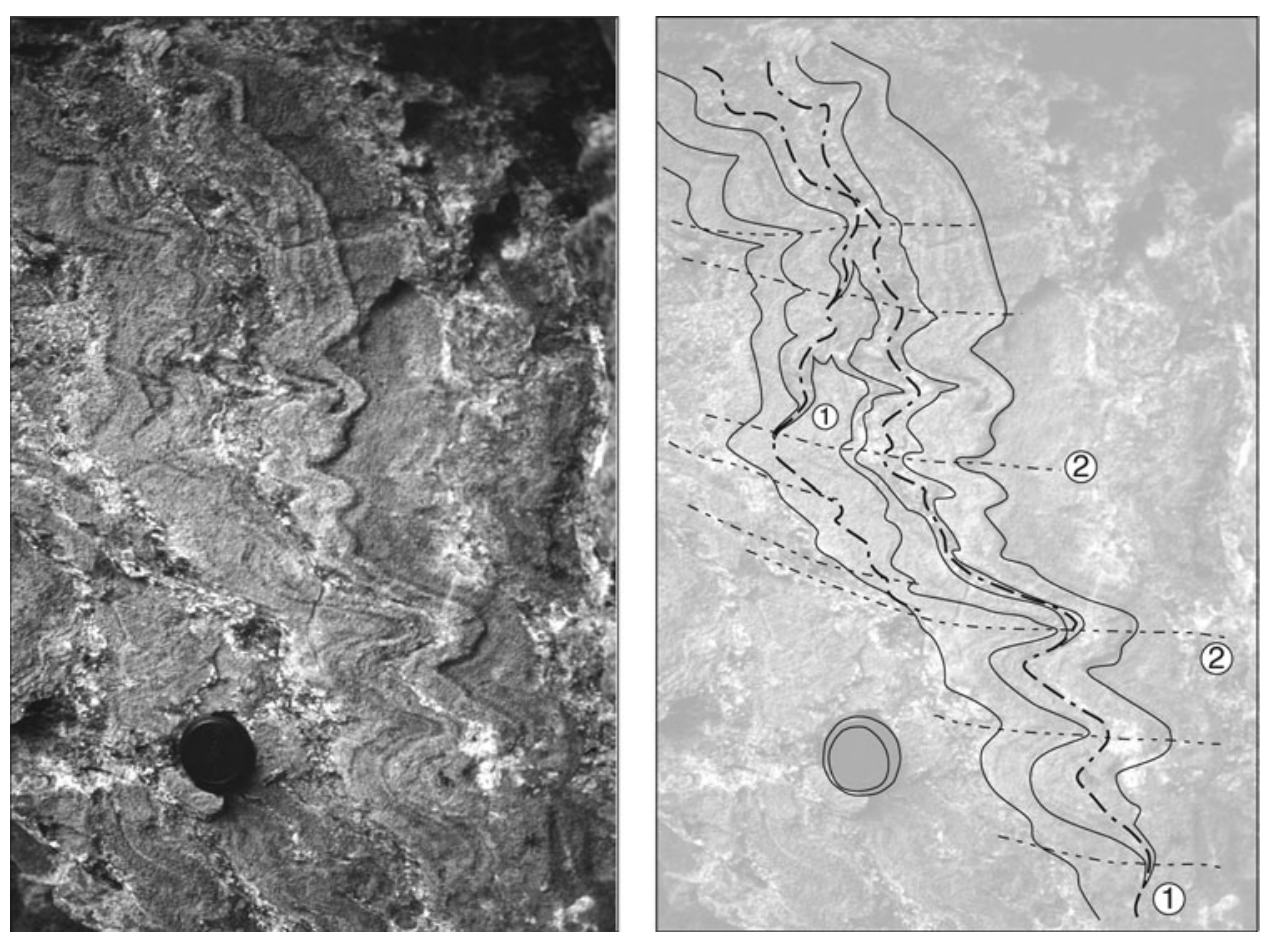

Fig. 10 Photographs and line drawings of overprinting relationships. a Sub-horizontal $\mathrm{S} 1$ foliation preserved in microlithons and sub-vertical spaced S2 schistosity; Permian conglomerates of the External Valais units (Moûtiers unit) in the Roselend pass area (French coordinates $\left.940^{\prime} 000 / 2^{\prime} 085^{\prime} 600\right)$; b representative example of F2 fold style, characterized by tight chevron-type similar folds; a strong component of homogeneous strain superimposed onto originally more open chevron folds is interpreted to have led to the observed similar fold geometry; St. Christophe Formation of the Internal Valais unit (=Versoyen unit)
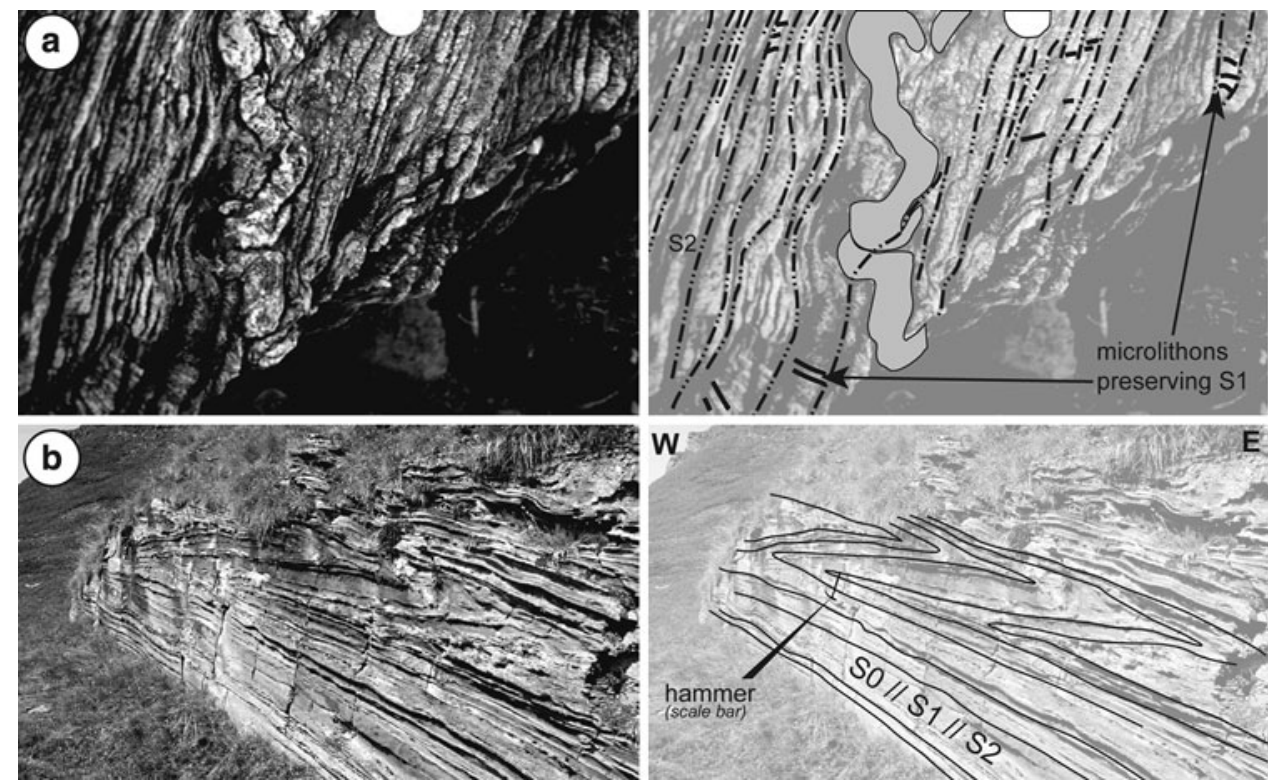

F2 fold axes gently plunge towards the $S$ (Fig. 8b), their orientation being close to that of L1 (Fig. 8a). A plunge towards $190^{\circ}-220^{\circ}$ dominates in the western and northwestern areas, turning more towards $180^{\circ}-150^{\circ}$ in the eastern and southeastern part of the study area (Fig. 8b). This change in orientation of the F2 fold axes is probably due to overprinting by F3 folds. These data contrast with the findings of Lancelot (1979) and Andrieux and Lancelot (1980) who describe an abrupt change in the orientation of the F2 folds axes that we cannot confirm. In the Tête de Beaupré area (Fig. 2), where post-D2-overprint is less pronounced, the $\mathrm{S} 2$ axial plane cleavage dips about $35^{\circ}$ towards $\mathrm{E}$ and $\mathrm{SE}$, and the dip of $\mathrm{F} 2$ folds is towards $180^{\circ}$ $150^{\circ}$ (Fig. 8b). Hence, it is proposed that the original orientation of D2-structures is best preserved in this area.

Late-D2-thrusting is prominent in the southern part of the study area, W and NE of Bourg St. Maurice (Fig. 2). In a geometrical sense, a series of thrusts is seen to truncate earlier-formed F2 fold axial planes. Stretching lineations measured along these thrusts are sub-parallel to lineations measured elsewhere within the S2 schistosity. This, and the fact that F3 folds overprint these thrusts, ascribes them to a 
late stage of D2. The major late-D2-thrusts mapped are the Leisette thrust W of Bourg St. Maurice and the Col des Rousses thrust NE of Bourg St. Maurice (Fig. 2). Due to lack of outcrop, the continuity between these two thrusts can only be suspected.

The late-D2 Leisette thrust defines the base of the Roc de l'Enfer unit (Fig. 2) separating it from the underlying Moûtiers and Versoyen units (Fig. 2). The Roc de l'Enfer unit is subdivided into three different sub-units, separated by minor late-D2-thrusts (see Loprieno 2001). The Leisette thrust truncates the late-D1-thrust contact between Versoyen unit and Moûtiers unit as seen in Figs. 2 and 6. In fact, the Leisette thrust is largely responsible for the disappearance of the Versoyen unit in map view towards the $\mathrm{S}$. There the Versoyen unit is buried underneath the Roc de l'Enfer unit (Fig. 2), its disappearance in map view being an apparent one.

The Col des Rousses late-D2-thrust (Fig. 2) is observed within the basaltic volcanic rocks and associated sediments of the Complexe Anteflysch of the Versoyen unit. Occurrences of evaporites mark the position of this thrust all the way from the Tête du Chargeur area (Bucher 1999) to the area near Bourg St. Maurice in the south (Figs. 2, 6). At the Tête du Chargeur, the Col des Rousses thrust also cuts across the earlier D1-thrust between Versoyen unit and Petit St. Bernard unit (Fig. 2) and causes the northern
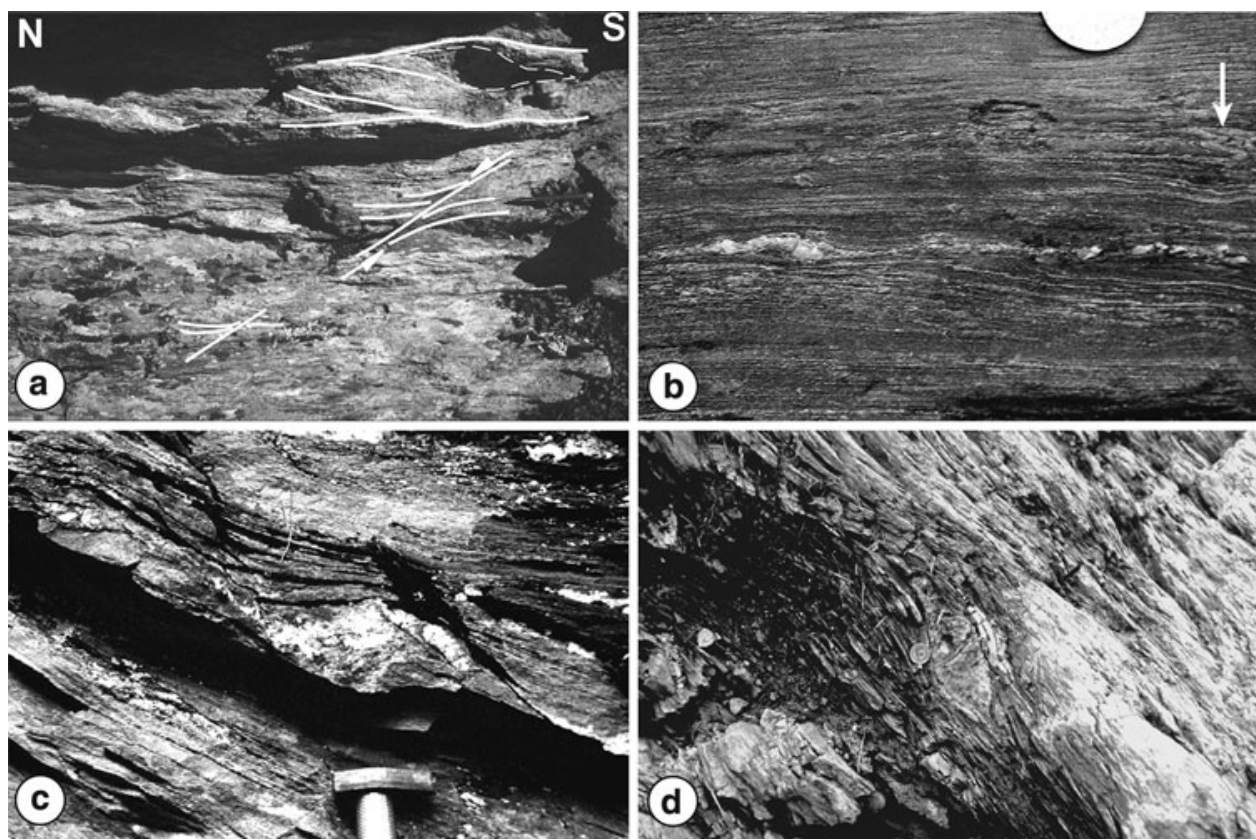

Fig. 11 Sense of shear criteria: a Shear bands indicating top-N (left) shearing in the Punta Rossa crystalline massif, shear bands and foliation cannot be unambiguously attributed to either D1 or D2. b Sigma clasts and folded relict S1 schistosity in the St. Christophe Formation of the Forclaz thrust sheet (part of the Roc de l'Enfer unit, Loprieno 2001) formed during late-D2 top-NNE (left) thrusting; c SE- termination of the Petit St. Bernard unit in map view (Fig. 2).

The gently SE-dipping late-D2-thrusts are associated with mylonites that contain stretching lineations and kinematic indicators such as shear bands or sigma clasts (Fig. 11b) indicating top-N transport during D2 (Fig. 8c). These mylonites, associated with the major late-D2-thrust plane (Leisette and Col des Rousses thrusts), are discordant to all older (D1 and early D2) planar structures preserved in the footwall. This late-D2-thrusting is out-of-sequence in the sense that the Leisette thrust carries the formerly more external Roc de l'Enfer unit over the Versoyen unit. At a regional scale, it also truncates the axial plane of the Versoye synform as is seen in Fig. 2 (see Loprieno 2001 for details).

\section{Post-D2 ductile normal faulting}

Post-D2 folding and pre-D3 folding, characterized by subhorizontal axial planes, is only observed at the eastern tip of the mapped area in the Valais units near Tête du Chargeur (Fig. 2). This folding is genetically related to a greenschist-facies ductile normal fault in the hangingwall of this zone. This normal fault is referred to as Pont Serrand normal fault zone and follows the contact between Valais units and Zone Houillère further to the NE all the way to Colle S. Carlo, NE of La Thuile (Bucher 1999;

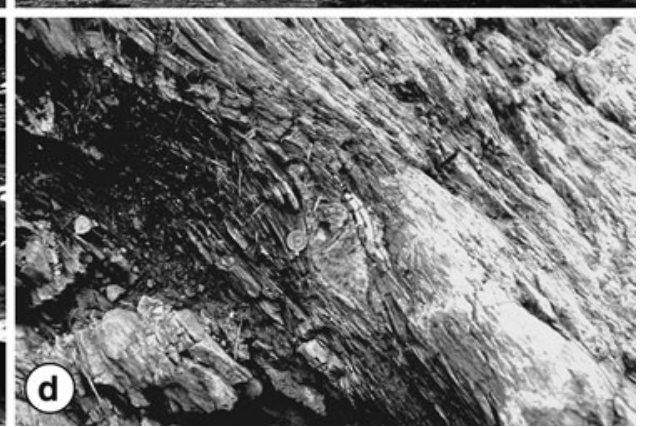

directed (right) shear bands in the Aroley Formation at the Colle San Carlo (Italy), east of the working area depicted in Fig. 2, formed during shearing associated with the post-D2 Pont Serrand ductile normal fault; d Top-WNW (left) shearing in the late-D3 mylonites along the Roselend thrust near Cormet de Roselend 
Loprieno 2001). Folding accommodates vertical shortening (Froitzheim 1992), post-dates D2 folding and is overprinted by D3 folding. SW of Tête du Chargeur, however, the contact between Valais units and Zone Houillère is marked by a younger (post-D3) brittle normal fault (Fügenschuh et al. 1999), which omits this older ductile normal fault zone.

Stretching lineations and kinematic indicators (Fig. 11c), observed within mylonitized post-rift sediments of the Versoyen unit, indicate top-ESE-directed normal faulting. The fold axes and axial planes of related reclined folds in the footwall of the mylonites gently dip towards SE; hence, fold axes and axial planes are oriented parallel to subparallel to stretching lineation and foliation of the overlying mylonites (for more details see Bucher 1999; Loprieno 2001).

D3-deformation and structural relationships with the underlying Dauphinois

Third-phase folding weakly affects most of the Valais units but becomes much more intense towards the NE, finally grading into mylonites formed during top-NW-directed late-D3 thrusting along the Roselend thrust at its type locality near Cormet de Roselend (Figs. 2, 6, 8d). This Roselend thrust (Loprieno 2001; Ceriani et al. 2001; Ceriani and Schmid 2004) forms the contact of the Valais units with the underlying Dauphinois units and largely coincides with the Penninic Front, also referred to as Penninic Basal Contact (Ceriani et al. 2001). Note that the trace of the Roselend thrust is oblique in respect of the strike of the nappe contacts amongst the different units derived from the Valais palaeogeographical domain (Fig. 2), and so are all the mesoscopic D3-structures within the Valais units (Figs. 6, 8d).

In the SE part of the area, D3 is only weakly expressed with the exception of the Punta Rossa area (Dalla Torre 1998). Further north-westward, large-scale D3 NW verging F3 folds can be traced across the entire nappe pile of Valais units (Fig. 6). The S3 schistosity, typically a crenulation cleavage, and macroscopic axial planes are generally oriented at a high angle to all the previous planar structures; axial planes and the associated $\mathrm{S} 3$ crenulation cleavage strike NE-SW and dip with about $60^{\circ}$ (Fig. 8d) towards SE. Such open F3 folds often produce type-3 interference patterns (Ramsay 1967).

Further NW and approaching the Roselend thrust, F3 folds become near isoclinal. All older planar structures (bedding, S1 and S2) merge into parallelism with the S3 foliation, which uniformly dips towards SE with a more gentle dip, parallel to the mylonites of the Roselend thrust. This late-D3 thrust forms the 1-km-wide NE-SW striking mylonite belt consisting of intensely deformed rocks of the Moûtiers unit and the underlying Dauphinois units. Along strike and from SW towards NE (Fig. 2), the mylonitic foliation defining the Roselend thrust systematically becomes steeper. The dips increase from around $35^{\circ}$ found in the SW at the Cormet de Roselend, also typical for areas even further SW (Ceriani et al. 2001), towards a sub-vertical orientation in the NE (Pyramides Calcaires). This steepening is due to late-stage folding that led to the updoming and erosion-assisted exhumation of the Mt. Blanc massif (Fügenschuh and Schmid 2003).

Numerous sense of shear indicators indicate top-WNW thrusting along the Roselend thrust (Fig. 11d). In the Pyramides Calcaires area, affected by subsequent steepening of the mylonites, the measurements of L3 were corrected by retro-rotation to the original dip and plotted together with the other L3 lineations in the pole figure shown in Fig. 8d (see Loprieno 2001 for details).

Figure 12 displays the view from Cormet de Roselend towards the Pyramides Calcaires, illustrating how the steeply dipping D3 foliation abruptly bends into parallelism with the more gently SE-dipping late-D3 Roselend thrust. The same observation can also be made in the hangingwall a minor top-WNW-directed late-D3 thrust at the base of the Pte. de Mya massif (Fig. 12) that is also discordant to earlier-formed F3 folds. This clearly indicates that the Roselend thrust developed during a late stage of D3.

A correlation of the Roselend thrust with structures observed in the underlying tectonic slices made up of sediments attributed to the Dauphinois realm (unité du Rocher du Vent and unité de la Crête des Gittes; Eltchaninoff and Triboulet 1980) shows that activity along the Roselend thrust was contemporaneous with the formation of a local D2 penetrative cleavage, which overprints an older D1-event in the Dauphinois realm. D2 becomes gradually more intense towards higher structural levels of the Dauphinois units, i.e., towards the Roselend thrust, grading into a mylonitic foliation (Gourlay 1986; Loprieno 2001). This D2-deformation in the Dauphinois is also topWNW and hence correlates with D3 in the Valais units and movement along the Roselend thrust. The first deformation event that led to nappe stacking in the Dauphinois formed in a scenario of sinistral transpression and is reported to be top-NNW (Eltchaninoff-Lancelot et al. 1982; Gourlay 1986). Hence, a similar change in the thrusting direction from a more northerly towards a more westerly direction is observed in the Dauphinois units. An evolution from top-NNW to top-WNW thrusting is also reported from the Helvetic units of western Switzerland (Ramsay 1989) and the Dauphiné units near the Pelvoux massif (Dumont et al. 2008).

D4 late-stage brittle normal faulting

A SE-dipping late normal fault (Fügenschuh et al. 1999) crosscuts all previous structures and can be followed from Moûtiers, SW of our area, all the way to Bourg St. Maurice and across the French-Italian border until 

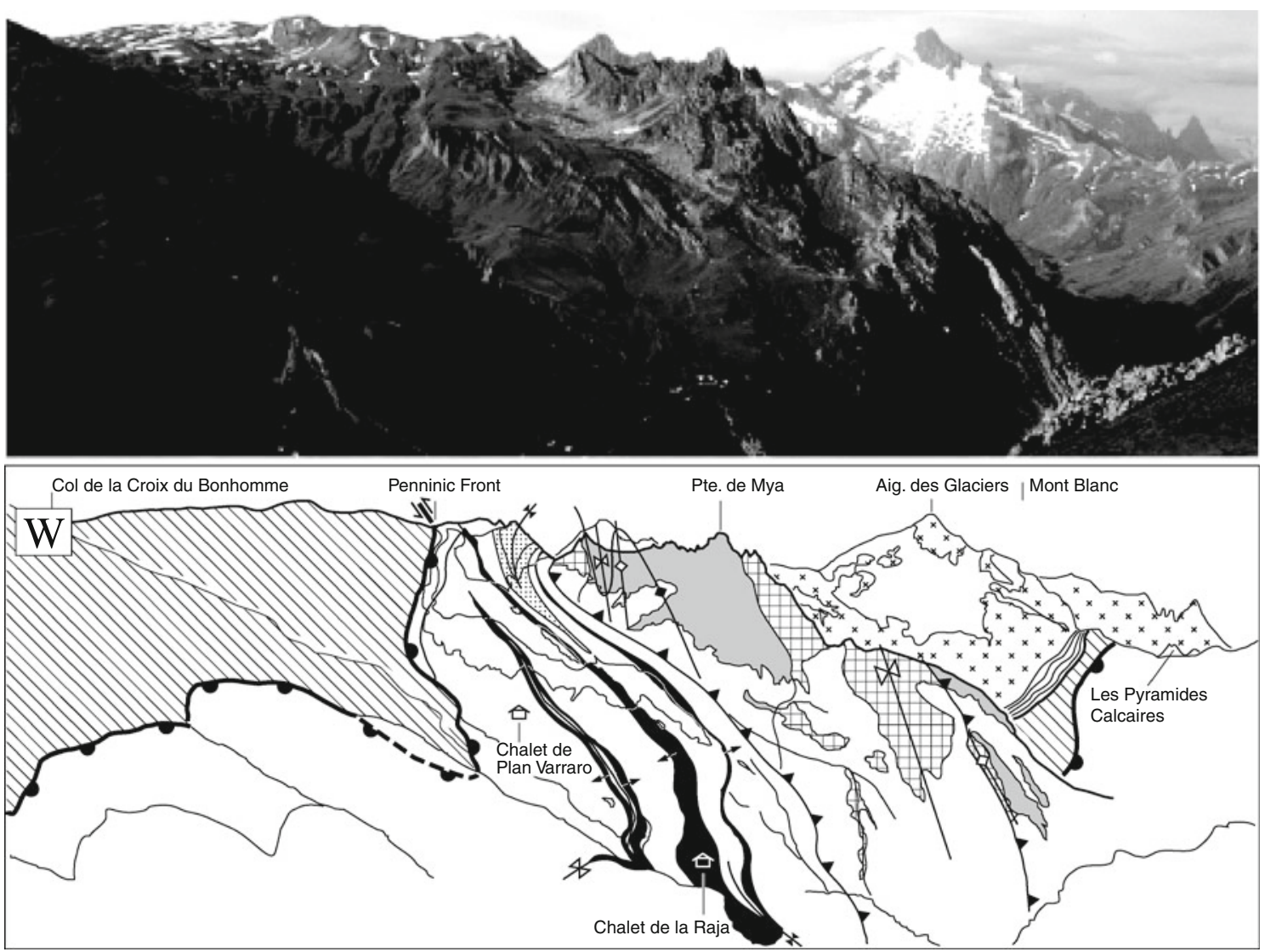

Dauphinois-Helvetic

Valais units (distal european margin, Moûtiers unit)

DVuphinois
$\begin{aligned} & \text { External Massifs: } \\ & \text { cover } \\ & \text { basement }\end{aligned}$

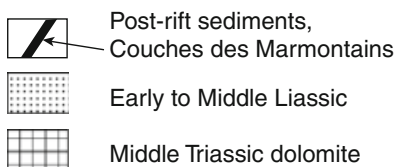

Permian and Early Triassic quartzite

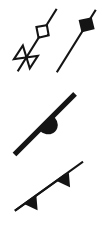

K Younging direction
D2 axial plane (black) D3 axial plane (white)

Roselend thrust Penninic Front (late-D3)

Minor D3 thrust

(coeval with the Penninic Front)

Fig. 12 Photograph and line drawing of the Penninic Front taken from the Cormet de Roselend area towards the Mt. Blanc massif, i.e. towards the NE

La Thuile. In the field, it is marked by an up to 50-m-wide steeply $\left(70^{\circ}-80^{\circ}\right)$ SE-dipping entirely brittle fault zone. This normal fault overprints the frontal thrust of the Zone Houillère that represents the westernmost unit of the Briançonnais (Bucher et al. 2004) as well as the earlier Pont Serrand ductile normal fault. This brittle normal fault presently forms the tectonic limit between the lowgrade metamorphosed rocks of the Zone Houillère and the Alpine HP-LT rocks of the Valais units (Fig. 7; Bucher and Bousquet 2004). However, since its vertical offset of 3-4 km according to fission track analysis (Fügenschuh et al. 1999) is not sufficient to produce such a large jump in grade of metamorphism, differential movement must have taken place during earlier phases of deformation (extrusion during D1 and/or D2; post-D2 Pont Serrand ductile normal fault).

\section{Large-scale structures and structural evolution}

Large-scale structures

The WNW-ESE-oriented sections presented in Fig. 13 cross the three major Valais units, namely the Moûtiers, Versoyen and Petit St. Bernard units. The sections show considerable differences with respect to those proposed by previous authors (Antoine 1971; Lancelot 1979; Antoine et al. 1992; Fudral 1980; Spencer 1989), both in terms of the stratigraphy outlined earlier and the major large-scale structures.

The central portions of both sections, with the Moûtiers unit underlying the Versoyen unit, are dominated by two large-scale D3 antiforms (Fig. 14), the cores of which expose the pre-rift sediments of the Moûtiers unit and are 

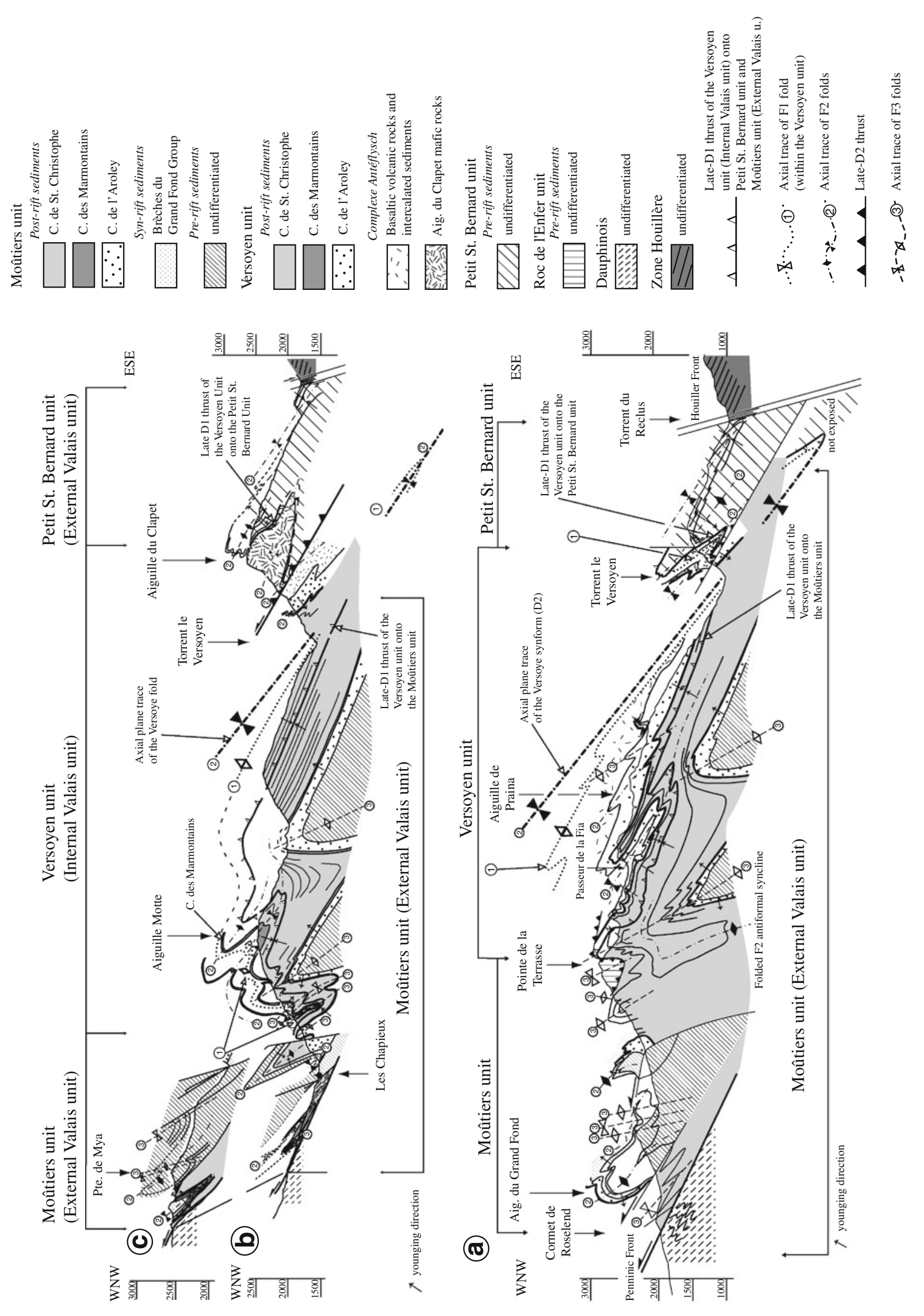

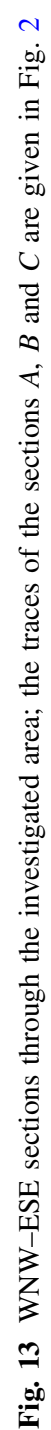




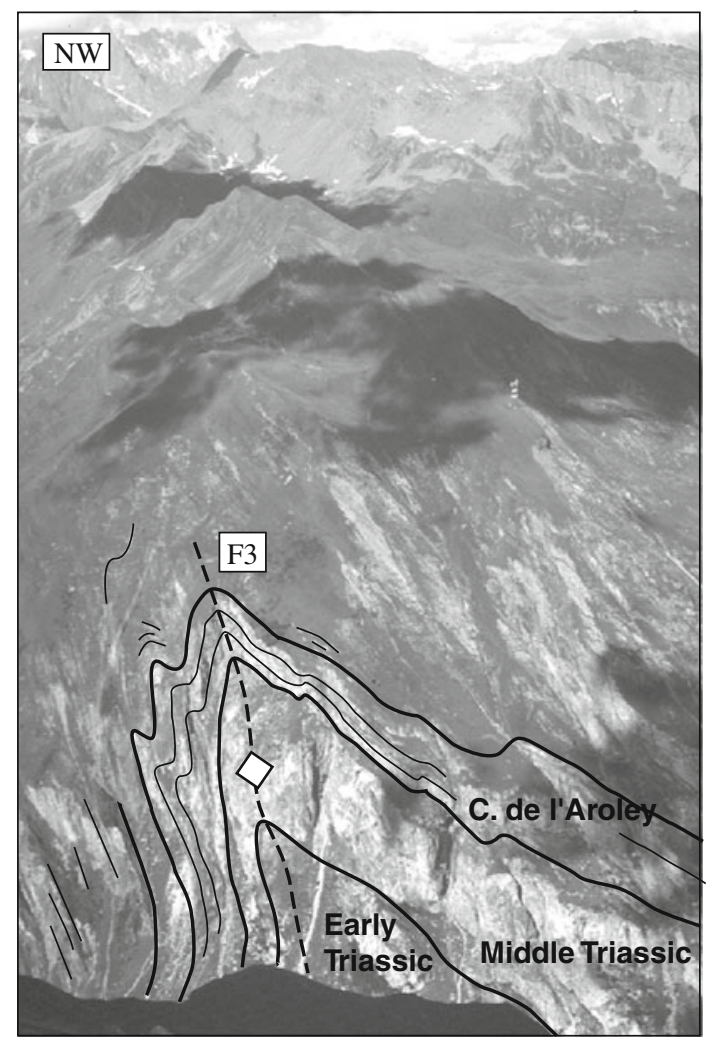

Fig. 14 Large-scale F3 fold in the Moûtiers unit (External Valais units) characterized by a steeply SE-dipping axial plane; $2 \mathrm{~km} \mathrm{SSE} \mathrm{of}$ les Chapieux, western slope of the Vallée des Glaciers

also recognizable in map view (Fig. 2). These folds deform all previous structures including the nappe contact with the overlying Versoyen unit. In the WNW, near the Roselend thrust, the F3 folds progressively become isoclinal and are associated with minor D3 thrusts. Large-scale interference patterns between F2 and F3 folds are recognizable in the Grand Fond massif (profile A in Fig. 13) and in the Pt. de Mya area (profile $\mathrm{C}$ in Fig. 13).

Prominent large-scale D2 folds are nicely depicted as well, particularly ESE of Pte. de la Terrasse (profile A in Figs. 13, 15a, b). These isoclinal D2 folds, whose axial planes are more gently inclined compared to those of F3, also affect the D1-thrust contact between the right-way-up Moûtiers unit and the tectonically overlying and overturned Versoyen unit (Fig. 15a, b). Note that, in both sections A and B (Fig. 13), these F2 megafolds exhibit a vergence that indicates a major synform further to the ESE, i.e. the Versoye synform, whose axial trace is mapped in Fig. 2 and constructed in sections A and B of Fig. 13. Since the nappe pile in the WNW part of the sections of Fig. 13 must be right-way-up, given the fact that the Valais units must have originally overlain the Dauphinois, the ESE part of the Valais units must be overturned. Hence, the D1-thrust contact between the Versoyen unit and the overlying Petit St. Bernard unit, overprinted by late-D2-thrusting and
Fig. 15 Panoramic views (photographs and line drawings) of: a, b the thrust fault between the Internal and External Valais units, isoclinally folded by a large-scale D2-parasitic fold exposed in the cliffs SW of the Vallée des Glaciers between Les Chapieux and Bourg St. Maurice; note that the sediments of the Moûtiers unit (External Valais units) are right-way-up while those of the overlying Versoyen unit (=Internal Valais unit) are overturned, and additionally, that the vergence of the large-scale parasitic folds indicates the location of this cliff section below the trace of the axial plane of the main Versoye D2-synform (compare section $A$ in the profile of Fig. 13); c, $\mathbf{d}$ the Aiguille du Clapet-Tête de Beaupré area showing the asymmetry of $\mathrm{W}$-facing F2 folds (see inset in circle), compatible with this area being located in the upper limb of the main D2-Versoye synform; note D2 folding of a late-D1-thrust contact between Petit St. Bernard and Versoyen units, also post-dating a D1-large-scale isoclinal fold with the Brèche du Collet des Rousses in its core; the exotic position of Late Triassic evaporites (tK) at the base of the Aiguille du Clapet marks a late-D2-thrust contact within the Versoyen unit; see also structural map of the same area depicted in Fig. 17a

located in the upper limb of the Versoye synform, must have been overturned by this $\mathrm{D} 2$ megafold. Isoclinal F2 folds with a vergence opposite to that found in the lower limb of the Versoye synform are indeed found in the Aiguille du Clapet area (Fig. 15c, d; see also section B of Fig. 13). This change in F2 vergence has been systematically mapped over the entire area and allowed to locate the trace of the Versoye D2 fold axial plane as shown in Figs. 2, 6 and 7. Near the ESE end of both sections of Fig. 13, the upper limb of the Versoye synform is followed by a D2-major antiform. This indicates that the inverted nappe stack in the upper limb of the Versoye synform eventually turns right-way-up, i.e. that the Versoyen unit must have originally overlain the Petit St. Bernard unit. Unfortunately, the upper limb of this D2-antiform and another parasitic synform were cut out during D4 brittle normal faulting, as is visible both in profile view (ESE edge of sections A and B in Fig. 13) and in map view (Fig. 2).

We conclude that, after retro-deformation of the Valais units into their pre-D2-configuration, the Versoyen unit (Internal Valais unit) must have overlain both the Moûtiers and the Petit St. Bernard units (parts of the External Valais units) that are connected around the hinge of the D2-Versoye synform. Unfortunately, no remnants of the Versoyen unit overlying the Petit St. Bernard unit are visible in map view due to the combined effect of erosion and omission along the D4 brittle normal fault. It is again emphasized that the NW edge of the Zone Houillère (Houiller Front of Fig. 2) does not represent the original D1 frontal thrust of the Zone Houillère over the Internal Valais unit (Versoyen unit).

Analysis of structural facing for inferring large-scale D1-structures

Also D1-deformation, responsible for the nappe stacking of Internal over External Valais units, was associated 


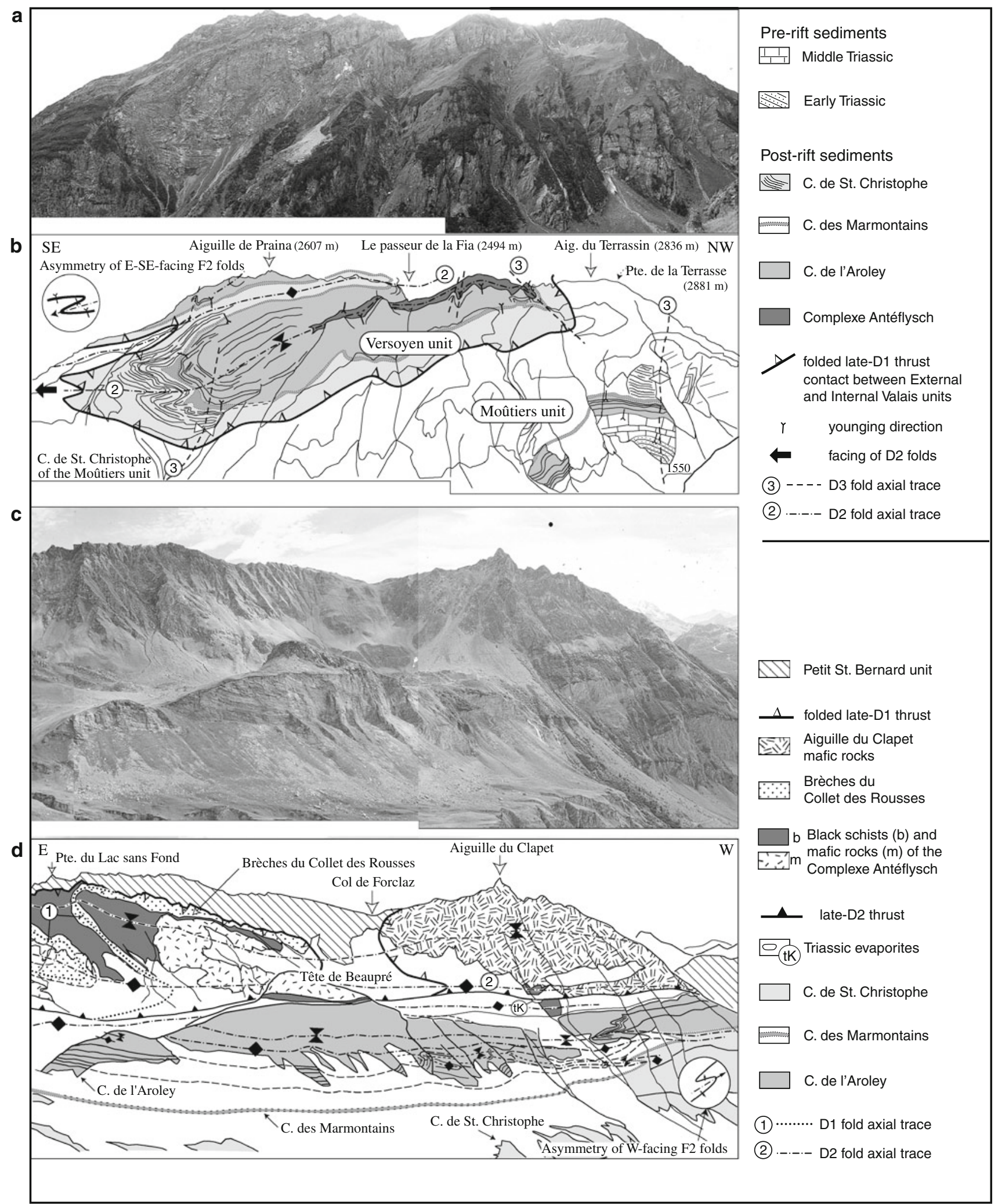

with large-scale isoclinal folding. However, such largescale isoclinal folds could only be seen in the SW slope of the Aiguille Motte (Fig. 16). The panorama depicted in Fig. 16 is an exception in that it exposes large-scale F1 folds, overprinted by D2 and D3. In general, the existence of F1 large-scale folds had to be inferred 


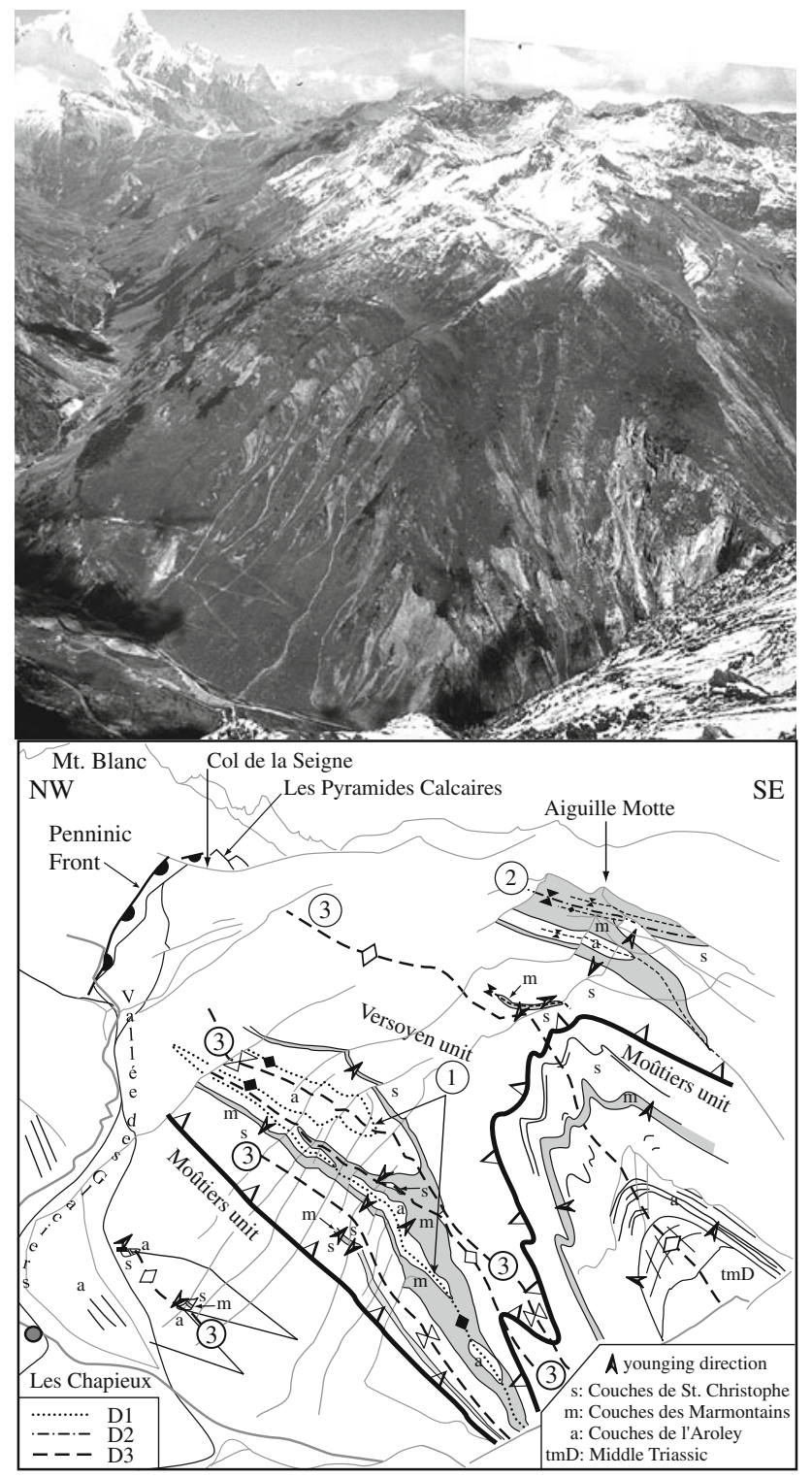

Fig. 16 Panorama and line drawing of the SW slope of the Aiguille Motte showing the axial trace of the large-scale F1 isoclinal fold and the D1-thrust contact between External Valais units (Moûtiers unit) and Internal Valais unit (=Versoyen unit); note that the post-rift sediments forming the Aiguille Motte peak are in stratigraphic contact with the Complexe Anteflysch formation further towards the SE as depicted in Fig. 4

via the analysis of structural facing, as is presented below.

D1 folding must obviously have affected parts of the area such as areas where the post-rift sediments of the Versoyen unit are overturned and tectonically overlie the rightway-up Moûtiers unit in the lower limb of the Versoye synform (Figs. 13, 15a). This configuration in the lower limb of the Versoye synform remains the same after retrodeformation of D2 folding and hence must have been caused by large-scale folding during the earlier D1-event.
The technique of observing and mapping reversals in the polarity of structural facing associated with small-scale D2 folding allows the mapping of D1-thrusts and the axial traces of major D1 folds and was also successfully used in other complexly deformed areas (e.g. Schreurs 1995). Note that the exact location of the D1-thrust in the lower limb of the D2-Versoye synform remains macroscopically invisible because it runs within parts of the St. Christophe Formation found above and below the D1-thrust (Fig. 15a); also, the hinges of major D1 folds remain invisible due to extremely intense D1 folding that obscures all major large-scale fold hinges in the area, with the exception of the Aiguille Motte area.

Figure 17a displays the result of mapping the changes in the facing direction (W versus $\mathrm{E}$ ) obtained for $\mathrm{N}-\mathrm{S}$-oriented D2 folds or D1/D2-intersection lineations. Note that in the western part of the mapped area (lower left part of Fig. 17), the right-way-up Moûtiers unit below the D1-thrust located in the lower limb of the Versoye D2-synform exhibits W-facing, while that of the overlying and overturned Versoyen unit exhibits E-facing (see also facing directions indicated in Fig. 15a). The change in structural facing indicates the location of the late-D1-thrust folded by D2. Moreover, the trace of a major D1 fold was mapped across the St. Christophe Formation in the lower (=western) limb of the Versoye D2-synform. The existence of this largescale F1 isoclinal fold indicates that the structurally higher parts of the Versoyen unit in the lower limb of the Versoye D2 folds are right-way-up. Since this D2-structural facing remains unchanged eastward, i.e. across the axial trace of the Versoye D2-synform, the majority of the Versoyen unit within the upper limb of the Versoye synform is also rightway-up. However, a narrow strip of the Versoyen unit in the upper limb of the Versoye D2-synform and below the late-D2-thrust at the base of the Petit St. Bernard unit around the Aiguille du Clapet again exhibits E-facing, i.e. became overturned by D1 folding. This points to the existence of D1 folds in the upper limb of the Versoye synform as well. The Petit St. Bernard unit, as well as the Roc de l'Enfer unit, exhibit W-facing and are right-way-up. This information provided by the analysis of structural facing is summarized in the form of a very schematic crosssection in Fig. 17b.

\section{Geometrical reconstruction and kinematic evolution}

Figure 18 very schematically illustrates the geometrical evolution; in particular, the evolving large-scale D1, D2 and D3 fold-interference patterns. Note, however, that shearing during the D2-event was top- $\mathrm{N}$, while shearing during D3 was top-WNW (Fig. 8c, d), and hence that both these shearing directions, as well as the $\mathrm{N}-\mathrm{S}$-trending D2 fold axes, are oblique to the section depicted in Fig. 18. 


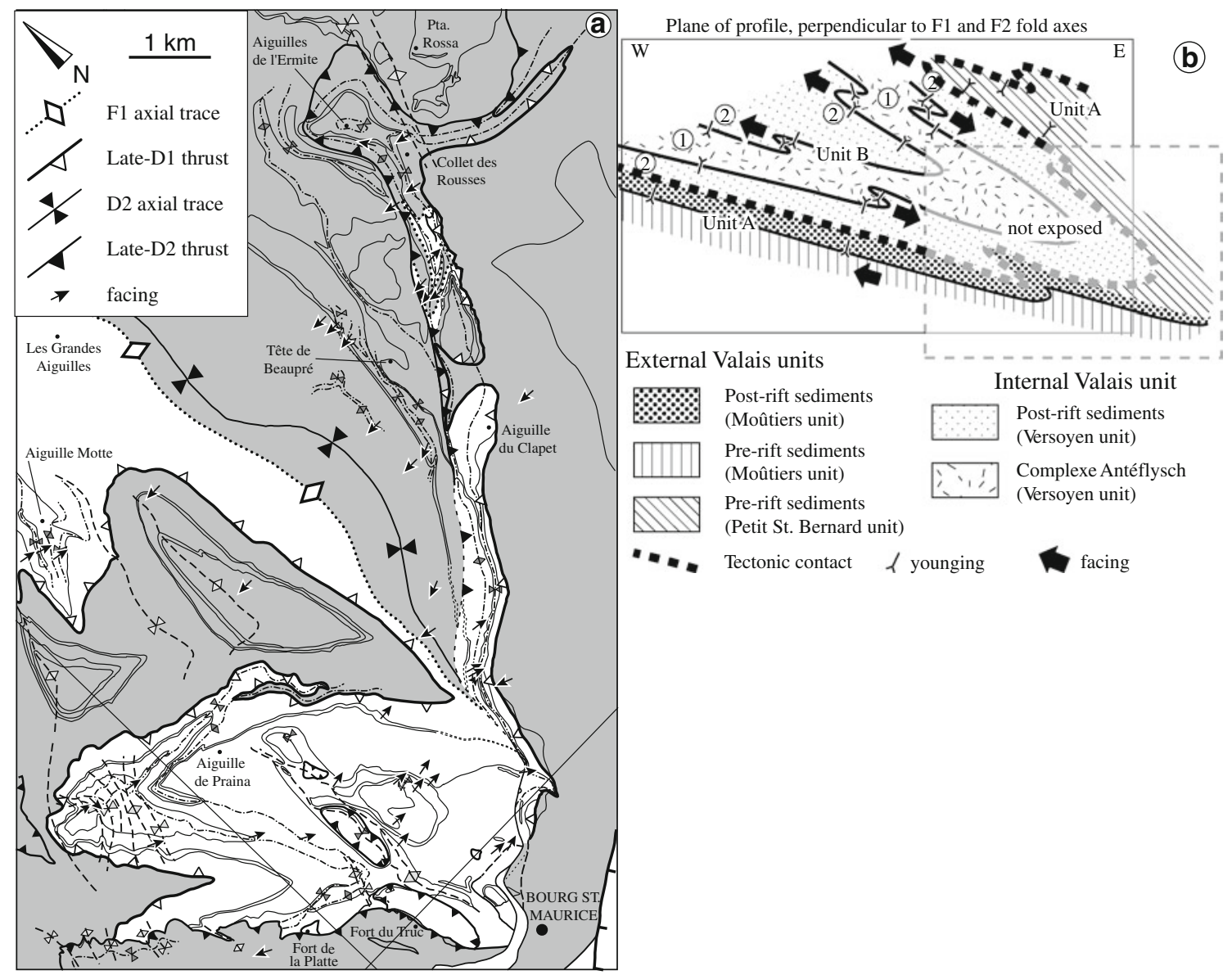

Fig. 17 Results of the analysis of structural facing of D2-structures (compare Fig. 18): a Detailed structural map indicating oppositefacing directions of $\mathrm{F} 2$ folds pointing to the existence of a major D1thrust and D1-isoclinal folds in an area between Bourg St. Maurice and the Collet des Rousses; grey areas encompass W-facing D2 folds located in the normal limb of a F1 isoclinal fold while white areas encompass E-facing D2 folds located in the inverted limb of a F1 isoclinal fold; b schematic profile depicting the macroscopic F1/F2 fold-interference pattern and based on the analysis of the map pattern

Also, note that for the purpose of simplicity Fig. 18 does not depict the effects of late-D2-thrusting that heavily affect the inverted limb of the F2 Versoye synform, as shown in the profiles of Fig. 13.

The first deformation event D1 started under peaktemperature conditions (stable chloritoid replacing carpholite in S1), following pre-D1-deformation under slightly higher pressures and particularly lower temperatures (Bousquet et al. 2002) that did not leave a structural record and led to the shearing-off of the Valais units from their former lithospheric underpinnings during subduction. D1 led to the formation of an isoclinal fold, followed by lateD1-thrusting of the inverted limb of the D1-isoclinal fold in the Versoyen unit over the External Valais units (Fig. 18a). Although top-N senses of shear that can unambiguously be of D2-structural facing and D2 fold asymmetries; the changes in facing are partly due to D1-thrusting (marked "tectonic contact") between units $A$ (Moûtiers unit and Petit St. Bernard unit) and $B$ (Versoyen unit) and partly due to the existence of a D1-isoclinal fold within the Versoyen unit, with the Complexe Antéflysch formation in its core; the effects of late-D2-thrusting at the base of the Petit St. Bernard and Roc de l'Enfer units that partly obscure the fold interference pattern were omitted in this schematic profile

attributed to L1 are lacking, the parallelism of L1 and L2, associated with top- $\mathrm{N}$-shearing, strongly suggests top- $\mathrm{N}$ nappe stacking amongst the Valais units during D1.

Concerning the metamorphic conditions, late-D1thrusting was responsible for the juxtaposition of the Internal Valais unit that suffered temperatures up to $500^{\circ} \mathrm{C}$ over the Petit St. Bernard and Moûtiers units where temperatures never exceeded $400^{\circ} \mathrm{C}$. This supports the view that D1-deformation and nappe stacking within the Valais units occurred during the exhumation of the high-pressure Valais units during top-N thrusting (see Fig. 7 in Fügenschuh et al. 1999).

The second phase of deformation (D2) led to near-isoclinal folding of the D1-nappe stack consisting of the Internal and External Valais units (Fig. 18b). Still later 


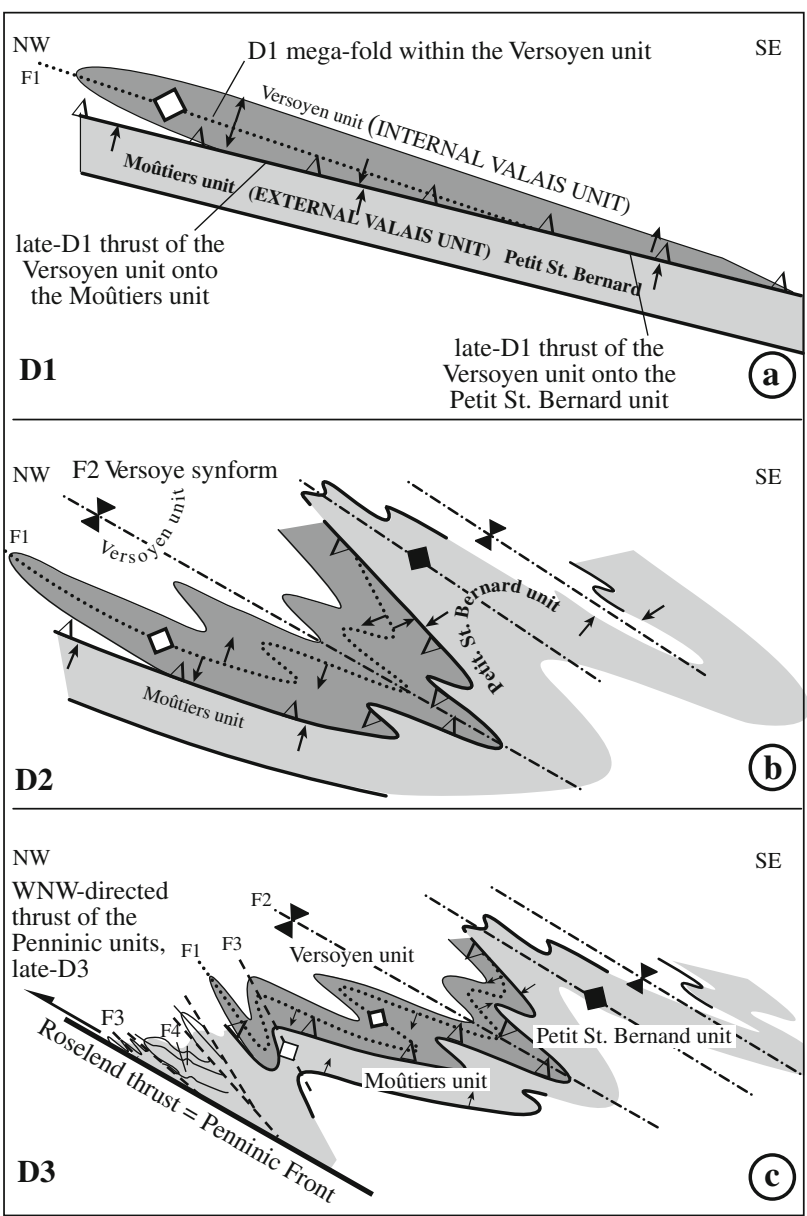

Fig. 18 Schematic SE-NW-oriented profiles across the Valais units depicting the evolution of the D1-, D2- and D3-structures and the complex geometrical relationships amongst the Versoyen, the Moûtiers and Petit St. Bernard units; arrows indicate younging directions; note that the Moûtiers unit was originally connected with the Petit St. Bernard unit and that the entire D1-nappe stack (Internal over External Valais units) is overturned in the upper limb of the D2Versoye synform; the effects of late-D2-thrusting at the base of the Petit St. Bernard and Roc de l'Enfer units were omitted in these schematic profiles

during D2, the structurally higher parts of the sketch shown in Fig. 18b became heavily overprinted by late-D2-thrusting that is unambiguously associated with top- $\mathrm{N}$ senses of shear (not shown in Fig. 18b for simplicity). The main effect of late-D2-thrusting was to finally emplace the Petit St. Bernard and Roc de l'Enfer units onto the Internal Versoyen along the Col des Rousses and Leisette thrusts, respectively (Fig. 2). Hence, in map view, it is this late-D2thrusting that is held responsible for the disappearance of the Versoyen unit towards the SW (Fig. 2). With the lateD2-thrust cutting, the D2-axial planes at a shallower angle the Versoyen unit simply becomes buried under the Roc de l'Enfer unit and the more internal Zone Houillère (Ceriani et al. 2001). In spite of the geometric superposition of D1- by D2-structures, everywhere visible on a mesoscopic and macroscopic scale, we interpret D2 folding and lateD2-thrusting to represent the late stages of a continuous kinematic evolution associated with top-N shearing, decompression and nappe stacking within the different Valais units already starting during D1. Post-D2 ductile normal faulting, only locally observed along the SE rim of the Valais units and not shown in Fig. 18, most likely represents the final stages of this early kinematic evolution.

An important change in terms of kinematics occurred, however, with the onset of D3 folding and top-WNW late-D3 thrusting along the Roselend thrust (Fig. 18c). The effects of D3 folding are very minor in the rear part of the Valais units, strain continuously increasing towards the Roselend thrust. This thrust brings the Valais units over the Dauphinois-Helvetic units and is associated with the latestage formation of the arc of the Western Alps (e.g. Ceriani et al. 2001).

Time constraints for the kinematic evolution

The fission track ages from within the area (Fügenschuh and Schmid 2003) document late-stage cooling, tilting and normal faulting rather well. Zircon central ages from the Valais units show that cooling through the partial annealing zone occurred between 17 and $9 \mathrm{Ma}$. The clear younging trend of the zircon and apatite fission track ages, going from ESE to WNW across the Valais units and adjacent tectonic units, is interpreted in terms of thrust propagation in the underlying units and associated progressive exhumation of the hangingwall by erosion, associated with the tilting of the Valais units in the back-limb of the culmination of the Mont Blanc External Massif (Fügenschuh and Schmid 2003). The latter was thrust during the late Miocene to early Pliocene onto the foreland (Leloup et al. 2005). This tilting also affected the D3 Roselend thrust that progressively steepens along strike towards the Mont Blanc area. This constrains D3 thrusting to have occurred before some $17 \mathrm{Ma}$ ago. Since D4 late-stage brittle normal faulting offsets the apatite ages, it must be still younger ( $<5$ Ma; Fügenschuh et al. 1999; Fügenschuh and Schmid 2003).

Interpretation of the fission track data from the Cheval Noir unit (Ceriani et al. 2003; Fügenschuh and Schmid 2003; Ceriani and Schmid 2004), which replaces the Valais units along strike in the south, indicate that cooling of the Penninic units in this area occurred as a consequence of erosion of the hangingwall when top-WNW thrusting along the D3 Roselend thrust started at around $32 \mathrm{Ma}$ ago (see discussion in Fügenschuh and Schmid 2003). This inference was recently confirmed by ${ }^{40} \mathrm{Ar} /{ }^{39} \mathrm{Ar}$ crystallization ages obtained on syn-kinematic phengite formed in shear zones within the Pelvoux basement (Simon-Labric et al. 2009). These shear zones are associated with top-WNW 
thrusting along the southern continuation of the Roselend thrust, i.e. the "Penninic Front", that hence must have occurred sometimes between 34 and $30 \mathrm{Ma}$. This is also in agreement with stratigraphic constraints indicating postPriabonian thrusting along the Roselend thrust (Ceriani et al. 2001). In the light of these findings, the few $\mathrm{Ar} / \mathrm{Ar}$ and $\mathrm{Rb} / \mathrm{Sr}$ phengite ages available from the Valais units within our area and ranging between 33 and $27 \mathrm{Ma}$ (Cannic 1996; Freeman et al. 1998) are also best explained as cooling ages induced by erosion of the hangingwall during D3 thrusting.

The age of the top-N D1-nappe stacking that was probably immediately followed by top- $\mathrm{N}$ near-isoclinal folding of the nappe stack is only indirectly defined by correlation with the immediately adjacent and more internal Briançonnais-derived units where new geochronological data have been obtained (Bucher 2003). Correlation of a local and well-dated deformation event D2 that is associated with nappe stacking and exhumation in this more internal area (Bucher et al. 2004, their Table 1) indicates a probable age range between 42 and 35 Ma for D1- and D2deformation in the Valais units. An estimate of the age of the pre-D1 pressure peak can be obtained by following the high-pressure belt formed during the subduction of the Valais ocean (Bousquet et al. 2008) further to the east into Switzerland. There, an age of 42-40 Ma was recently inferred from ${ }^{40} \mathrm{Ar} /{ }^{39} \mathrm{Ar}$ dating of white mica formed during the high-pressure overprint of the Valais Bündnerschiefer (Wiederkehr et al. 2009). In conclusion, pre-D1 subduction, top-N D1-nappe stacking and top-N D2-nappe refolding probably occurred within a rather short interval of time during the Late Eocene, i.e. between some 42 and $35 \mathrm{Ma}$.

\section{Discussion and conclusions}

Implications regarding the existence of a Valais ocean and the timing of its opening

The idea that the Valais palaeogeographical units, originally defined by Haug (1909) taken up by Trümpy (1955), merely represent a small basin floored by continental crust that found its closure towards the southwest in the Vocontian trough of the Chaînes Subalpines as part of the Dauphinois palaeogeographical realm is an old and deeply entrenched one, particularly in the Italian and French literature (e.g. Lemoine 1985; Polino et al. 1990; Dercourt et al. 1993; Lemoine et al. 2000). Often, the oceanic nature of parts of the rocks of the Versoyen is either denied or ignored; occasionally, it is recognized but interpreted as representing slices of the Piemont-Liguria ocean, originally thrust over the Briançonnais continental fragment and caught later by an out-of-sequence thrust below the Briançonnais (e.g. Bocquet 1974). On the other hand, plate kinematic (e.g. Frisch 1979; Stampfli 1993) and geological data (e.g. Steinmann 1994; Florineth and Froitzheim 1994; Stampfli et al. 1998; Steinmann and Stille 1999) indicate that a second and northerly branch of the Alpine Tethys led to the break-away of a Briançonnais microcontinent from Europe along the Valais ocean, connected to oblique spreading in the Bay of Biscay and the future Pyrenees that significantly post-dates the mid-Jurassic opening of the Piemont-Liguria ocean.

Recently, Masson et al. (2008) presented stratigraphic and tectonic arguments from our area that apparently denies the existence of a Valais ocean. According to these authors, the "Versoyen ophiolites" simply represent a piece of the Variscan orogen; the ophiolites would represent a Carboniferous-age complex that is in Alpine-tectonic contact with the Valais trilogy. In contrast, our own stratigraphic data basically confirm and consolidate those of Antoine (1971) and Fudral (1998): the contact between the Complexe Antéflysch and the Valais trilogy is clearly a stratigraphic one (Fig. 5). Hence, the Valais trilogy represents the stratigraphic cover of both the Internal and External Valais units that together represent an oceancontinent transition zone. All the sediments of the Valais units, particularly those of the Complexe Antéflysch Formation and the Valais trilogy, are intensely folded and sheared; however, our mapping and structural analysis revealed an orderly and consistent geometry of a multiply folded stack of sediments within which there is no room for a "Supra-Tarentaise wildflysch" supposedly marking a thrust at the base of the Versoyen ophiolites, as claimed by Masson et al. (2008; their Figs. 3, 4) at Mont Miravidi. This contact at Mont Miravidi (see Fig. 2 for location) simply represents an overturned stratigraphic contact between Complexe Antéflysch Formation and Valais trilogy, as previously recognized by Antoine (1971) and Fudral and Guillot (1988). The downward younging direction within the Complexe Antéflysch Formation at this locality, also challenged by Masson et al. (2008), is undisputable as can be easily seen in less-deformed parts within the Moûtiers unit of the External Valais units.

Moreover, in order to support their model of a tectonic emplacement of the pre-Alpine "Versoyen ophiolites", Masson et al. (2008) attributed the Brèches du Collet des Rousses Formation to the Mesozoic cover of the Petit St. Bernard unit. These authors did this in spite of (1) clear evidence for a stratigraphic contact with the Complexe Antéflysch Formation (Loubat 1975; Schürch 1987; Dalla Torre 1998) and (2) clear indications for a tectonic contact between Complexe Antéflysch Formation and Petit St. Bernard unit, a contact often marked by evaporites (Loprieno 2001). Hence, the stratigraphic and structural 
arguments presented in support of a pre-Alpine age of the "Versoyen ophiolites" by Masson et al. (2008) are in strong contrast to virtually all the data presented in this study.

The data on the age of mafic and felsic rocks found within the Internal Valais unit, however, are problematic, and hence our scheme regarding the distinction between Complexe Antéflysch Formation and Punta Rossa Complex presented in Fig. 3 merits a serious discussion and also calls for further work. The ages published so far, all based on $\mathrm{U} / \mathrm{Pb}$ dating of zircons, range from $337 \pm 4.1 \mathrm{Ma}$ (Masson et al. 2008) over $309 \pm 6 \mathrm{Ma}$ (Schärer et al. $2000)$ to $272 \pm 2 \mathrm{Ma}$ and $267+1 \mathrm{Ma}$, respectively (Beltrando et al. 2007). As a consequence, the important question arises as to whether the dated mafics and granitoids, which are part of the Punta Rossa Complex, represent a piece of Variscan basement exhibiting pre-Alpine deformation and metamorphism, or alternatively, postVariscan magmatic rocks of Permian age, deformed and metamorphosed during the Alpine cycle. In the light of our stratigraphic and structural data, as well as very detailed mapping (Dalla Torre 1998), we prefer the second option that would indicate bimodal magmatism typical for Permian times and found in many other parts of the Alps that expose lower crustal rocks, later exhumed near an ocean-continent transition (Rubatto et al. 1999; Handy et al.1999; Hermann et al. 1997; Froitzheim and Rubatto 1998; Manatschal et al. 2006).

We emphasize that the mafic sills and serpentinites of the Complexe Antéflysch Formation still remain undated. Their attribution to a pre-Barremian-Aptian rifting and drifting event related to the opening of the Valais ocean still needs to be tested. At this stage, this inference is primarily based on, first, the presence of serpentinites, interpreted to have been emplaced on the ocean floor near an ocean-continent transition in Cretaceous times as is documented for the Pyrenees (Lagabrielle and Bodinier 2008) and the Valais units of the Alps (Froitzheim and Rubatto 1998; Manatschal et al. 2006), and second, on the geochemical signatures of the mafic sills (Mugnier et al. 2008).

Based on these considerations, we propose that the Valais units within the area represent the European distal continental margin (External Valais units) adjacent to an ocean-continent transition preserved in the Internal Valais unit (Versoyen). Of course, the Internal Valais unit does not represent a Cyprus-type ophiolitic sequence but a magma-poor rifted margin associated with the exhumation of subcontinental mantle so typical for Alpine ophiolites and the Iberian margin (Manatschal 2004; Lagabrielle and Bodinier 2008). The stratigraphic data from the External Valais units also demonstrate that parts of the Valais palaeogeographical domain in the sense of Trümpy (1955) were definitely not floored by oceanic lithosphere. In our area, it is only the Internal Valais unit that preserves associations formed near the ocean-continent transition during modest and oblique spreading in the PyreneanAlpine realm in Cretaceous times (Frisch 1979; Stampfli 1993). These are topped by the deposition of post-rift sediments of the Valais trilogy from the Barremian-Aptian onwards.

Finally, we emphasize that Cretaceous age rifting and drifting typical for the Valais domain affected a preexisting passive margin characterized by the typical Subbriançonnais facies. This margin obviously formed during previous (i.e. Jurassic age) rifting that led to the opening of the Piemont-Liguria ocean. Hence, the area must have suffered two rifting events. Due to massive syn- and postrift erosion and poor dating, the evidence we provided regarding the existence of two cycles of syn-rift sedimentation preserved within the Brèches du Grand Fond Group remains to be consolidated.

Implications on the orogenic evolution of the Western Alps

The compilation of the metamorphic evolution presented in Fig. 7 indicates that all the Valais units, including the External Valais units, were affected by a high-pressure overprint. However, there is a substantial gradient in the peak pressures reached ranging between about $8 \mathrm{kbar}$ in the most external Moûtiers unit to some 17 kbar reached in the most internal Petit St. Bernard and Versoyen units. The latter two entered the eclogite field when they underwent heating during the initial phases of decompression from preceding blueschist-facies conditions. Hence, the Valais units formed a second and more external high-pressure belt in comparison with the Piemont-Liguria belt in the Alps that evolved during the Middle Eocene, presumably around 42-40 Ma ago. This external high-pressure belt is separated from the more internal suture zone that formed earlier, i.e. at some $47 \mathrm{Ma}$ (Bucher et al. 2003), along the internal side of the Briançonnais microcontinent (Bousquet et al. 2008; Wiederkehr et al. 2008, 2009) by the greenschist-facies Zone Houllière (Fig. 7). It is important to stress the fact that not only the ocean-continent transition zone represented by the Internal Valais unit did go into subduction, but also the distal European margin of the External Valais units. This is similar to the findings in Eastern Switzerland, where sediments of the distal European margin (Peidener Schuppenzone with Ultrahelvetic facies) also suffered high-pressure overprint (Wiederkehr et al. 2008).

The substantial pressure gradient within the Valais units indicates that the difference in subduction depth between Internal and External Valais units originally, i.e. before the onset of D1-deformation, amounted to some $30 \mathrm{~km}$. 
Differential exhumation during D1-nappe stacking practically eliminated this depth difference as is seen from the sketch depicted in Fig. 18a. This is in line with the microstructural inference that peak-pressure conditions were reached before the onset of D1-deformation (Fügenschuh et al. 1999, see also their Fig. 7).

Late Eocene top-N D1-nappe stacking, immediately followed by top-N D2 near-isoclinal folding of the nappe stack (Fig. 18b, c), probably represent incremental steps during a progressive deformation. D1 was associated with erosional exhumation, and the emplacement of the Internal Valais unit (Versoyen) onto the External Valais units. On the scale of the arc of the Western Alps, this progressive deformation must have occurred in a scenario of sinistral transpression when the Adriatic microplate, moving northward with respect to the European foreland (Handy et al. 2010 in press), caused sinistral transpression in the Western Alps (Ricou and Siddans 1986; Schmid and Kissling 2000), while the Central and Eastern Alps underwent head-on convergence and collision with Europe at the same time (Schmid et al. 1996). Top-N D1- and D2-deformation was terminated by a first extensional event when the Pont Serrand normal fault cut out units at the rear of the Valais units, overprinting the former Briançonnais frontal thrust (Bucher et al. 2004).

A major change was initiated with top-WNW D3deformation associated with the Roselend thrust after some $35 \mathrm{Ma}$ (Ceriani et al. 2001). This led to a second stage of arc formation that accentuated the arc of the Western Alps as a consequence of the WNW-directed movement of the Adriatic microplate by some $250 \mathrm{~km}$ (Handy et al. 2010 in press). The latter was decoupled from the central and eastern Alps along the Tonale-Simplon dextral shear zone and from the Ligurian domain by a sinistral transfer zone (Laubscher 1991; Schmid and Kissling 2000). The latestage Roselend thrust can be followed down to a depth of almost $15 \mathrm{~km}$ before it flattens according to the interpretation of the deep structure along the ECORS-CROP seismic profile by Schmid and Kissling (2000). It delimits the base of seismically highly reflective zone representing the subsurface continuation of the Late Eocene Valais suture.

Late-stage tilting of the Valais units in the back-limb of the culmination of the Mont Blanc External Massif (Fügenschuh and Schmid 2003), thrust in Miocene to Early Pliocene onto the foreland (Leloup et al. 2005), had little effect on the internal structures found within the area and merely led to tilting of the D3 Roselend thrust along strike increasing towards the Mont Blanc area. Post-5 Ma brittle normal faulting (Fügenschuh et al. 1999) caused further tectonic omission at the rear of the Valais units, i.e. along the contact zone with the Zone Houillère. Along strike and further south also the Roselend thrust was overprinted by Neogene to recent normal faulting (Sue and Tricart 2003).
Conclusions

We conclude that

(1) The Valais units in Savoy represent the heavily deformed relics of the former distal European margin (External Valais units), affected for the first time by Jurassic rifting, and an ocean-continent transition (Internal Valais unit) formed during a second Cretaceous age rifting that led to the opening of a northern branch of the Alpine Tethys.

(2) The post-rift sediments of the Valais trilogy stratigraphically overlie both the External and Internal Valais units above an unconformity that formed in Barremian-Aptian times, providing robust evidence for the timing of the opening of the Valais ocean immediately before Barremian-Aptian times.

(3) The Valais units in Savoy represent a second and more external Mid-Eocene high-pressure belt in the Alps that sutured the Briançonnais microcontinent with Europe.

(4) Top-N D1 folding and thrusting led to the formation of the original nappe stack, emplacing the Internal Valais unit (Versoyen) that undergoes decompression and heating onto the External Valais units, which consisted of, from internal to external, Petit St. Bernard unit, Roc de l'Enfer unit, Moûtiers unit and Quermoz unit. Ongoing top-N D2 folding and D2thrusting substantially modified this nappe stack.

(5) Post-35 Ma D3 folding led to relatively minor modifications within the Valais nappe stack but was associated with substantial top-WNW thrusting of the Valais units over the Dauphinois realm along the Roselend thrust that accentuated the arc of the Western Alps.

Acknowledgments We appreciate generous funding of Alpine research of the Basel group by the Swiss Science Foundation over many years. S. M. Schmid also acknowledges financial support by the Alexander von Humboldt Foundation during his 1-year stay at FU Berlin, invited by Mark Handy who is thanked for fruitful discussions during this stay. We thank P. Nievergelt for markedly improving the quality of the illustrations. D. Bernoulli (Basel), as well as the official reviewers P. Tricart (Grenoble) and Y. Gouffon (SwissTopo Bern), is thanked for their very careful look at the manuscript; their corrections led to considerable improvement of an earlier version of the manuscript.

\section{References}

Allemann F (1957) Geologie des Fürstentums Liechtenstein (Südwestlicher Teil) unter besonderer Berücksichtigung des Flyschproblems. Jahrbuch der Historischen Vereinigung Lichtensteins 56:1-244

Andrieux J, Lancelot JC (1980) Les plis "transverses" postpriaboniens dans la Zone des Brèches de Tarentaise. C R Acad Sci Paris 290:1059-1061 
Antoine P (1965) Sur l'existence du Crétace supérieur daté dans la nappe des Brèches de Tarentaise au Nord des Chapieux (Savoie). CR Acad Sci Paris 261:3640-3642

Antoine P (1971) La Zone des Brèches de Tarentaise entre BourgSaint-Maurice (Vallée de l'Isère) et la frontière Italo-suisse. Travaux du Laboratoire Géologie de l'Université de Grenoble Mémoires 9:1-367

Antoine P, Barbier R, Debelmas J, Fudral S (1972) Précisions chronologiques et paléogéographiques sur les brèches du Massif du Grand-Fond (zone des Brèches de Tarentaise, Savoie). Géol Alp 48:49-59

Antoine P, Barféty JC, Vivier GJ, Debelmas J, Desmons J, Fabre J, Loubat H, Vautrelle C (1992) Notice explicative de la Carte géologique de France 1/50 000. Feuille Bourg-Saint-Maurice 727:1-110

Antoine P, Barféty JC, Vivier GJ, Gros Y, Fudral S, Landry P, Fabre H (1993) Carte géologique de France (1/50 000). Feuille BourgSaint-Maurice 727

Bagnoud A, Wernli R, Sartori M (1998) Découverte de foraminifères planctoniques dans la zone de Sion-Courmayeur à Sion. Eclogae Geol Helv 91:421-429

Barbier R (1948) Les zones Ultradauphinoise et Subbriançonnaise entre l'Arc et l'Isère. Mémoires pour servir à l'explication de la Carte Géologique détaillée de la France. Thèse Faculté des Sciences de Strasbourg, $291 \mathrm{pp}$

Beltrando M, Rubatto D, Compagnoni R, Lister G (2007) Was the Valaisan basin floored by oceanic crust? Evidence of Permian magmatism in the Versoyen unit (Valaisan domain, NW Alps). Ofioliti 32:85-99

Bocquet J (1974) Études minéralogiques et pétrologiques sur les métamorphismes d'âge alpin dans les Alpes françaises. Thèse Université Grenoble France, 489 pp

Bousquet R, Goffé B, Vidal O, Oberhänsli R, Patriat M (2002) The tectono-metamorphic history of the Valaisan domain from the Western to the Central Alps: new constraints for the evolution of the Alps. Geol Soc Am Bull 114:207-225

Bousquet R, Oberhänsli R, Goffé B, Wiederkehr M, Koller F, Schmid SM, Schuster R, Engi M, Berger A, Martinotti G (2008) Metamorphism of metasediments at the scale of an orogen: a key to the tertiary geodynamic evolution of the Alps. In: Siegesmund $\mathrm{S}$, Fügenschuh B, Froitzheim N (eds) Tectonic aspects of the alpine-dinaride-carpathian system. Geol Soc Lond Spec Publ 298:393-412

Bucher S (1999) Petrographische und strukturgeologische Untersuchungen am Kleinen St. Bernhard Pass (Zone Valaisanne, Punta Rossa Komplex, Unité du Pt. St. Bernard), Teil 2. Diploma Thesis Geologisch-Paläontologisches Institut der Universität Basel, pp 1-73

Bucher S (2003) The Briançonnais units along the ECORS-CROP transect (Italian-French Alps): structures, metamorphism and geochronology. $\mathrm{PhD}$ thesis University Basel, $175 \mathrm{pp}$

Bucher S, Bousquet R (2004) Metamorphic evolution of the Briançonnais units along the ECORS-CROP profile (Western Alps): new data on metasedimentary rocks. Swiss J Geosci 100:227-242

Bucher S, Schmid SM, Bousquet R, Fügenschuh B (2003) Late-stage deformation in a collisional orogen (Western Alps): nappe refolding, back-thrusting or normal faulting? Terra Nova 15:109-117

Bucher S, Ulardic C, Bousquet R, Ceriani S, Fügenschuh B, Schmid SM (2004) Tectonic evolution of the Briançonnais units along the ECORS-CROP transect through the Italian-French Western Alps. Eclogae Geol Helv 97:321-345

Burri M (1979) Les formations valaisannes dans la région de Visp. Eclogae Geol Helv 72:789-802

Cannic S (1996) L'évolution magmatique et tectono-métamorphique du substratum du domaine valaisan (Complexe du Versoyen,
Alpes occidentales): implications dans l'histoire alpine. Thèse de doctorat Université Joseph Fourier Grenoble France, 215 pp

Cannic S, Lardeaux JM, Mugnier JL, Hernandez J (1995) Tectonometamorphic evolution of the Roignais-Versoyen unit (Valaisan domain, France). Eclogae Geol Helv 89:321-343

Ceriani S, Schmid SM (2004) From N-S collision to WNW-directed post-collisional thrusting and folding: structural study of the Frontal Penninic units in Savoie (Western Alps, France). Eclogae Geol Helv 97:347-369

Ceriani S, Fügenschuh B, Schmid SM (2001) Late-stage thrusting at the "Penninic Front" in the Western Alps between Mont Blanc and Pelvoux massifs. Int J Earth Sci 90:685-702

Ceriani S, Fügenschuh B, Potel S, Schmid SM (2003) Tectonometamorphic evolution of the Frontal Penninic units of the Western Alps: correlation between low-grade metamorphism and tectonic phases. Schweiz Mineral Petrogr Mitt 83:111-131

Dalla Torre FH (1998) Petrographische und strukturgeologische Untersuchungen am Kleinen St. Bernhard Pass (Zone Valaisanne, Punta Rossa Komplex, Unité du Pt. St. Bernard), Teil 1. Diploma Thesis at Geologisch-Paläontologisches Institut der Universität Basel, pp 1-106

Debelmas J, Caby R, Desmons J (1991) Notice explicative. Carte géologique de la France (1/50000) feuille 728 Ste-Foy-Tarentaise. BRGM, Orléans

Dercourt J, Ricou LE, Vrielinck B (1993) Atlas Tethys, paleoenvironmental maps. Gauthier-Villars, Paris, p 307

Dietrich V, Oberhänsli R (1975) Die Pillow-Laven des Vispertales. Schweizerische. Schweiz Mineral Petrogr Mitt 55:79-87

Dumont T, Champagnac JD, Crouzet C, Rochat P (2008) Multistage shortening in Dauphiné (French Western Alps): record of Alpine collision and implications for pre-Alpine restoration. Swiss $\mathbf{J}$ Geosci 101:89-110

Einsele G (1985) Significance basaltic sill-sediment complexes in young spreading centers: genesis and significance. Geology 13:249-252

Eltchaninoff C, Triboulet S (1980) Étude Géologique entre Belledonne et Mont Blanc. Livre synthétique Travaux du Département de Géotectonique de l'Université Pierre et Marie Curie à Paris, pp $1-54$

Eltchaninoff-Lancelot C, Triboulet S, Douboux B, Fudral S, Rampnoux JP, Tardy M (1982) Stratigraphie et tectonique des unités delphino-helvétiques comprises entre Mont-Blanc et Belledonne (Savoie Alpes occidentales). Implications régionales. Bull Soc Geol Fr 24:817-830

Elter P (1951) Observations géologiques dans le Val Veny (Versant italien du Mont Blanc). Archives des sciences et Compte Rendu des séances de la société de physique et d'histoire naturelle de Genève 4:427-429

Elter P (1954) Etudes géologiques dans le Val Veni et le vallon du Breuil (Pt. St. Bernard). Thèse No 1200, Université de Genève

Elter P, Elter G (1957) Sull' existenza, nei dintorni del Piccolo San Bernardo, di un elemento tettonico riferibile al ricoprimento del Pas du Roc. Rend Acad Naz Lincei 22:181-187

Elter G, Elter P (1965) Carta geologica della regione del Piccolo S. Bernardo (versante italiano). Note illustrative. Memorie Istituto Geologico Mineralogico Università Padova 25:1-53

Epard JL (1990) La nappe de Morcles au sud-ouest du Mont-Blanc. Mémoires de Géologie (Lausanne) 8:1-165

Florineth D, Froitzheim N (1994) Transition from continental to oceanic basement in the Tasna nappe (Engadine window, Graubünden, Switzerland): evidence for early cretaceous opening of the Valais ocean. Schweiz Mineral Petrogr Mitt 74:437-448

Franchi S (1900) Nuove località con fossili mesozoici nelle zone delle pietre verdi presso il colle del Piccolo San Bernardo (Valle d'Aosta). Bollettino del R. Comitato Geologico 10:305 
Freeman SR, Butler RWH, Cliff RA, Inger S, Barnicoat AC (1998) Deformation migration in an orogen-scale shear zone array: an example from the basal Briançonnais thrust, internal FrancoItalian Alps. Geol Mag 135:349-367

Frisch W (1979) Tectonic progradation and plate tectonic evolution of the Alps. Tectonophysics 60:121-139

Froitzheim N (1992) Formation of recumbent folds during synorogenic crustal extension (Austroalpine nappes, Switzerland). Geology 20:923-926

Froitzheim N, Rubatto D (1998) Continental break-up by detachment faulting: field evidence and geochronological constraints (Tasna nappe, Switzerland). Terra Nova 10:171-176

Froitzheim N, Schmid SM, Frey M (1996) Mesozoic paleogeography and the timing of eclogite-facies metamorphism in the Alps: a working hypothesis. Eclogae Geol Helv 89:81-110

Fudral S (1973) Contribution à l'étude de l'unité de Moûtiers (zone des Brèches de Tarentaise) entre le vallon du torrent du Cormet d'Arêches et le hameau des Chapieux. Thèse 3ème cycle, Université Grenoble, 129 pp

Fudral S (1980) Une nouvelle interprétation de l'unité de Salins (zone des Brèches de Tarentaise) au nord-ouest de Bourg St. Maurice (Savoie). Conséquences structurales. C R Acad Sci Paris 290:1333-1336

Fudral S (1998) Etude géologique de la suture téthysienne dans les Alpes franco-italiennes nord occidentales de la Doire Ripaire (Italie) à la région de Bourg Saint-Maurice (France). Géol Alp Mémoire H.S. 29 du Laboratoire de Géologie de l'Université de Grenoble, pp 1-306

Fudral S, Guillot P (1988) Découverte de clastes à mariposite dans les conglomérats de la base du "Flysch de Tarentaise" (zone valaisanne), Savoie, France. Conséquences. C R Acad Sci Paris 306(Série II):911-914

Fügenschuh B, Schmid SM (2003) Late stages of deformation and exhumation of an orogen constrained by fission track data: a case study in the Western Alps. Geol Soc Am Bull 115:1425-1440

Fügenschuh B, Loprieno A, Ceriani S, Schmid SM (1999) Structural analysis of the Subbriançonnais and Valais units in the area of Moûtiers (Savoy, Western Alps): paleogeographic and tectonic consequences. Int J Earth Sci 88:201-218

Gely JP, Bassias Y (1990) Le front pennique: implications structurales d'un métamorphisme transporté (Savoie, France). C R Acad Sci Paris 310:37-43

Goffé B, Bousquet R (1997) Ferrocarpholite, chloritoide et lawsonite dans les métapelites des unités du Versoyen et du Petit St Bernard (zone valaisanne, Alpes occidentales). Schweiz Mineral Petrogr Mitt 77:137-147

Goffé B, Schwartz S, Lardeaux JM, Bousquet R (2004) Explanatory notes to the map: metamorphic structure of the Alps. Mitt Österr Mineral Ges 149:125-144

Gourlay P (1986) La déformation du socle et des couvertures delphino-helvétiques dans la région du Mont-Blanc (Alpes occidentales). Bull Soc Geol Fr 8ème série, tome II, No. 1:159-169

Grasmück KP (1961) Die helvetischen Sedimente am Nordostrand des Mont Blanc-Massivs (zwischen Sembrancher und dem Col Ferret). Eclogae Geol Helv 54:351-450

Handy MR, Franz L, Heller F, Janot B, Zurbriggen R (1999) Multistage accretion and exhumation of the continental crust (Ivrea crustal section, Italy and Switzerland). Tectonics 18:1154 1177

Handy MR, Schmid SM, Bousquet R, Kissling E, Bernoulli D (2010) Reconciling plate-tectonic reconstructions of Alpine Tethys with the geological-geophysical record of spreading and subduction in the Alps. Earth Sci Rev. doi:10.1016/j.earscirev.2010.06.002 (in press)

Haug E (1909) Les géosynclinaux de la chaîne des Alpes pendant les temps secondaires. C R Acad Sci Paris 148:1637
Hermann J, Müntener O, Trommsdorff V, Hansmann W, Piccardo GB (1997) Fossil crust-to-mantle transition, Val Malenco (Italian Alps). J Geophys Res 102:20123-20132

Hesse R (1973) Flysch-Gault und Falknis-Tasna-Gault (Unterkreide): Kontinuierlicher Übergang von der distalen zur proximalen Flyschfazies auf einer penninischen Trogebene der Alpen. Geologica et Paleontologica SB2:1-90

Homewood P, Ackermann T, Antoine P, Barbier R (1984) Sur l'origine de la nappe du Niesen et la limite entre les zones ultrahelvétique et valaisanne. C R Acad Sci Paris Série II 299:1055-1059

Jeanbourquin P (1994) The lower Penninic nappes in the western Alps: the link between Helvetic and Penninic. J Struct Geol 16:895-898

Jeanbourquin P (1995) The lower Penninic nappes in the Western Alps: the link between Helvetic and Penninic: reply. J Struct Geol 17:1485-1488

Jeanbourquin P, Burri M (1991) Les metasediments du Pennique inférieur dans la région de Brigue-Simplon-Lithostratigraphie, structure et contexte géodynamique dans le basin Valaisan. Eclogae Geol Helv 84:463-481

Jenkyns H (1980) Cretaceous anoxic events: from continents to oceans. J Geol Soc London 137:171-188

Kelts K (1981) A comparison of some aspects of sedimentation and translational tectonics from the Gulf of California and the mesozoic Tethys. Eclogae Geol Helv 74:317-338

Lagabrielle Y, Bodinier JL (2008) Submarine reworking of exhumed subcontinental mantle rocks: field evidence from the Lherz peridotites, French Pyrenees. Terra Nova 20:11-21

Lancelot JC (1979) Etude tectonique de la zone des brèches de Tarentaise dans la région de Bourg-Saint-Maurice, Savoie. Thèse Université de Paris

Laubscher H (1991) The arc of the western Alps today. Eclogae Geol Helv 84:631-659

Leloup PH, Arnaud N, Sobel ER, Lacassin R (2005) Alpine thermal and structural evolution of the highest external crystalline massif: the Mont Blanc. Tectonics 24:TC4002. doi:10.1029/ 2004TC001676

Lemoine M (1985) Structuration jurassique des Alpes occidentales et palinspastiques de la Téthys ligure. Bull Soc Geol Fr Série 8 tome $\mathrm{I} / 1: 126-137$

Lemoine M, de Graciansky P, Tricart P (2000) De l'océan à la chaîne de montagnes: tectonique des plaques dans les Alpes. Gordon and Breach, $194 \mathrm{pp}$

Lomas S (1992) Submarine mass-flow conglomerates of the Tarentaise zone, Western Alps: sedimentation processes and depositional setting. Sediment Geol 81:269-287

Loprieno A (2001) A combined structural and sedimentological approach to decipher the evolution of the Valais domain in Savoy, Western Alps. Dissertationen aus dem GeologischPaläontologischen Institut der Universität Basel, vol 18, pp 1-285

Loubat H (1968) Etude pétrographique des ophiolites de la zone du Versoyen, Savoie (France), province d'Aoste (Italie). Archives des Sciences et Compte Rendu des Séances de la Société de Physique et d'Histoire Naturelle de Genève 21:265-457

Loubat H (1975) La zone du Versoyen: Témoin possible d'une intersection entre dorsale océanique et marge continentale. Archives des Sciences et Compte Rendu des Séances de la Société de Physique et d'Histoire Naturelle de Genève 28:101-116

Loubat H (1984) Considérations préliminaires sur la configuration horizontale de l'édifice subvolcanique du Versoyen (Alpes franco-italiennes) analogue aux basins en distension du type Golfe de Californie. Geol Alp 60:37-44

Loubat H, Delaloye M (1984) La zone du Versoyen (Alpes francoitaliennes): le témoin d'une océanisation mésozoïque circonscrit 
constituant un milieu hybride, subvolcano-sédimentaire, avec mobilisats et adinoles. Geol Alp 60:45-76

Manatschal G (2004) New models for evolution of magma-poor rifted margins based on a review of data and concepts from West Iberia and the Alps. Int J Earth Sci 93:432-466

Manatschal G, Engström A, Desmurs L, Schaltegger U, Cosca M, Müntener O, Bernoulli D (2006) What is the tectono-metamorphic evolution of continental break-up: the example of the Tasna Ocean-Continent Transition. J Struct Geol 10:1849-1869

Masson H, Bussy F, Eichenberger M, Giroud N, Meilhac C, Presniakov S (2008) Early carboniferous age of the Versoyen ophiolites and consequences: non-existence of a "Valais ocean" (Lower Penninic, western Alps). Bull Soc Geol Fr 179:337-355

Mugnier JL, Cannic S, Lapierre H (2008) The tholeiites of the Valaisan domain (Versoyen, western Alps): a Carboniferous magma emplaced in a small oceanic basin. Bull Soc Geol Fr 179:357-368

Oberhänsli R, Bousquet R, Goffé B (2003) Comment to 'Chloritoid composition and formation in the eastern central Alps: a comparison between Penninic and Helvetic occurrences'. Schweiz Mineral Petrogr Mitt 83:341-344

Oberhänsli R, Bousquet R, Engi M, Goffé B, Gosso G, Handy M, Höck V, Koller F, Lardeaux JM, Polino R, Rossi P, Schuster R, Schwartz S, Spalla MI (2004) Metamorphic structure of the Alps. Commission for the Geological Map of the World, Paris

Polino R, Dal Piaz GV, Gosso G (1990) The Alpine cretaceous orogeny: an accretionary wedge model based on integrated stratigraphic, petrologic and radiometric data. In: Roure F, Heitzmann P, Polino R (eds) Deep structure of the Alps. Mem Soc Geol Fr 156:345-367

Ramsay G (1967) Folding and fracturing of rocks. McGraw-Hill, New York, $568 \mathrm{pp}$

Ramsay JG (1989) Fold and fault geometry in the western Helvetic nappes of Switzerland and France and its implication for the evolution of the arc of the western Alps. In: Coward MP, Dietrich D (eds) Alpine tectonics. Geol Soc Lond Spec Publ 45:33-45

Ricou LE, Siddans AWB (1986) Collision tectonics in the western Alps. In: Coward MP, Ries AC (eds) Collision tectonics. Geol Soc Lond Spec Publ 19:229-244

Rubatto D, Gebauer D, Compagnoni R (1999) Dating of eclogitefacies zircons: the age of Alpine metamorphism in the SesiaLanzo Zone (Western Alps). Earth Planet Sci Lett 167:141-158

Rück P (1995) Stratigraphisch-sedimentologische Untersuchungen der Schamser Decken. In: the Schams nappes part 1. Beiträge zur Geologischen Karte der Schweiz 167:1-76

Saliot P (1979) La jadéite dans les Alpes françaises. Bull Soc Française Min Crist 102:391-401

Schärer U, Cannic S, Lapierre H (2000) Preliminary evidence for a Hercynian age of the Versoyen complex, western Alps. C R Acad Sci Paris Sciences de la Terre et des Planètes 330:325-332

Schmid SM, Kissling E (2000) The arc of the Western Alps in the light of geophysical data on deep crustal structure. Tectonics 19:62-85

Schmid SM, Pfiffner OA, Froitzheim N, Schönborn G, Kissling E (1996) Geophysical-geological transect and tectonic evolution of the Swiss-Italian Alps. Tectonics 15:1036-1064

Schmid SM, Fügenschuh B, Kissling E, Schuster R (2004) Tectonic map and overall architecture of the Alpine orogen. Eclogae Geol Helv 97:93-117
Schreurs G (1995) Structural analysis of the Schams nappes and adjacent tectonic units in the Pennine zone. In: The Schams nappes part 2. Beiträge zur Geologischen Karte der Schweiz 167:77-128

Schürch ML (1987) Les ophiolites de la zone du Versoyen: témoin d'un bassin à évolution métamorphique. Thèse de doctorat Université Genève, pp 1-157

Schwizer B (1983) Die Tristel-Formation. Vergleichende Untersuchung in Graubünden, Liechtenstein, Vorarlberg und Bayern. Ph.D. Thesis Bern University, 186 pp

Serre A, Toury A, Rampnoux JP, Martinez-Reyes J, Tardy M (1985) Individualisation de deux unités à flysch nummulitique d'origines paléogéographiques différentes au sein de "l'écaille ultradauphinoise des Aiguilles d'Arve" (région de Saint-Jean de Maurienne, Savoie). C R Acad Sci Paris 301:637-642

Simon-Labric T, Rolland Y, Dumont T, Heymes T, Authemayou C, Corsini M, Fornari M (2009) 40Ar/39Ar dating of Penninic Front tectonic displacement (W Alps) during the lower oligocene (31-34 Ma). Terra Nova 21:127-136

Sodero D (1968) Sull' età Barremiano-Aptiano delle formazioni basali del "Flysch" della Zona delle Breccie di Tarentasia in Valle d'Aosta. Boll Soc Geol It 87:223-231

Spencer S (1989) Nature of the North Pennine Front: French Alps. $\mathrm{PhD}$ thesis at Imperial College, London

Stampfli GM (1993) Le Briançonnais: terrain exotique dans les Alpes? Eclogae Geol Helv 86:1-45

Stampfli GM, Mosar J, Marquer D, Marchant R, Baudin T, Borel G (1998) Subduction and obduction processes in the Swiss Alps. Tectonophysics 296:159-204

Steinmann M (1994) Ein Beckenmodell für das Nordpenninikum der Ostschweiz. Jahrbuch der Geologischen Bundesanstalt 137:675-721

Steinmann M, Stille P (1999) Geochemical evidence for the nature of the crust beneath the eastern North Penninic basin of the Mesozoic Tethys ocean. Geol Rundsch 87:633-643

Sue C, Tricart P (2003) Neogene to ongoing normal faulting in the inner western Alps: a major evolution of the late alpine tectonics. Tectonics 22/5:1050. doi:10.1029/2002TC001426

Trümpy R (1951) Sur les racines helvétiques et les "Schistes lustrés" entre le Rhône et la Vallée de Bagnes (Région de la Pierre Avoi). Eclogae Geol Helv 44:338-342

Trümpy R (1954) La zone de Sion-Courmayeur dans la haut Val Ferret valaisan. Eclogae Geol Helv 47:315-359

Trümpy R (1955) Remarques sur la corrélation des unités penniques externes entre la Savoie et le Valais et sur l'origine des nappes préalpines. Bull Soc Geol Fr V:217-231 6ème série tome

Trümpy R (1963) Sur les racines des nappes helvétiques. Société Géologique de France mém h s tome II. Livre à la mémoire du Prof. P. Fallot 2:419-428

Wiederkehr M, Bousquet R, Schmid SM, Berger A (2008) From subduction to collision: thermal overprint of HP/LT metasediments in the north-eastern Lepontine Dome (Swiss Alps) and consequences regarding the tectono-metamorphic evolution of the Alpine orogenic wedge. In: Froitzheim N, Schmid SM (eds) Orogenic processes in the Alpine collision zone. Swiss J Geosci 101/Suppl 1:S127-S155

Wiederkehr M, Sudo M, Bousquet R, Berger A, Schmid SM (2009) Alpine orogenic evolution from subduction to collisional thermal overprint: the $40 \mathrm{Ar} / 39 \mathrm{Ar}$ age constraints from the Valaisan ocean, Central Alps. Tectonics 28(TC6009):1-28. doi:10.1029/ 2009TC002496 